\title{
SCHIFF BASES DERIVED FROM HYDROXYARYL ALDEHYDES: MOLECULAR AND CRYSTAL STRUCTURE, TAUTOMERISM, QUINOID EFFECT, COORDINATION COMPOUNDS
}

\author{
Anita Blagus ${ }^{1}$, Dominik Cinčićé2, Tomislav Friščić2§, Branko Kaitner²*, Vladimir Stilinovićc \\ ${ }^{1}$ Department of Chemistry, J. J. Strossmayer University, Franje Kuhača 20, 31000 Osijek, Croatia \\ ${ }^{2}$ Laboratory of General and Inorganic Chemistry, Department of Chemistry, Faculty of Science, \\ University of Zagreb, Horvatovac 102a, 10000 Zagreb, Croatia \\ sPresent address: Department of Chemistry, University of Cambridge, Lensfield Road, Cambridge CB2 1EW, UK \\ kaitner@chem.pmf.hr
}

\begin{abstract}
During the last 50 years a vast number of structural studies on Schiff bases derived from hydroxyaryl aldehydes and their coordination compounds have been undertaken. In this review we present a systematic and brief overview of the most important discoveries and achievements accomplished in this field. The occurrence of Schiff bases (and their complexes) derived from nine most commonly used hydroxyaryl aldehydes in the Cambridge Structural Database (CSD) has been investigated. Keto-enol tautomerism and intramolecular hydrogen bonding in salicylaldimines and naphthaldimines is discussed, with a comment of the most common errors in determining the correct tautomeric form. Also, the interrelationship of crystal packing and the substituents on the Schiff base is studied. Finally, we give a short overview of conformational differences between free Schiff bases and Schiff bases bonded to metal ions as well as some structural characteristics of Schiff base metal complexes.
\end{abstract}

Key words: Schiff bases; Schiff base complexes; tautomerism; quinoid effect; supramolecular interaction

\section{ШИФОВИ БАЗИ ДОБИЕНИ ОД ХИДРОКСИАРИЛ АЛДЕХИДИ: МОЛЕКУЛСКА И КРИСТАЛНА СТРУКТУРА, ТАВТОМЕРИЈА, ХИНОНСКИ ЕФЕКТ, КООРДИНАЦИОНИ СОЕДИНЕНИЈА}

Во последните 50 години се направени голем број структурни истражувања на Шифовите бази добиени од хидроксиарилалдехиди и нивни координациони соединенија. Во овој прегледен труд е презентирано систематско и кратко согледување на најзначајните откритија и достигнувања направени на ова поле. Проучувано е добивањето на Шифовите бази (и нивните комплекси) од девет најчесто користени хидроксиарилалдехиди според структурната база на податоци во Кембриџ. Кето-енолната тавтомерија и интрамолекуларното водородно сврзување кај салицилалдимините и нафталдимините е дискутирано со давање посебен коментар на најчестите грешки при одредувањето на правилната тавтомерна форма. Освен тоа, проучувана е поврзаноста на кристалното пакување со супституентите на Шифовата база. Презентиран е и краток осврт на конформациските разлики помеѓу слободните Шифови бази и Шифовите бази сврзани со метални јони, како и на некои структурни карактеристики на металните комплекси со Шифовите бази.

Клучни зборови: Шифови бази; комплекси со Шифови бази; тавтомерија; хинонски ефект; супрамолекулска интеракција 


\section{INTRODUCTION}

$N$-substituted imines, also known as Schiff bases represent one of the most widely used families of organic compounds and their chemistry is essential material in many organic chemistry textbooks [1-3]. In general, they are easily prepared by the condensation reaction of primary amines with carbonyl compounds. The first reports of this kind of reaction have been published by Hugo Schiff in the 1860s [4-6]. Thereafter Schiff bases have been intensively used as synthetic intermediates and as ligands for coordinating transition and inner transition metal ions, and recently also for coordinating anions [7-9]. During the past two decades they have become some of the most typical ligands in the field of coordination chemistry [10-16]. Particularly, a large number of transition metal complexes of Schiff base ligands derived from the condensation of salicylaldehyde and 2-hydroxy-1-naphthaldehyde with various primary amines became the topic of contemporary research [10, 17-21]. These Schiff base ligands may act as bidentate $\mathrm{N}, \mathrm{O}$-, tridentate $\mathrm{N}, \mathrm{O}, \mathrm{O}-, \mathrm{N}, \mathrm{O}, \mathrm{N}-\mathrm{N}, \mathrm{N}, \mathrm{O}, \mathrm{S}-$, tetradentate $\mathrm{N}, \mathrm{N}, \mathrm{O}, \mathrm{O}-$, hexadentate $N, N, O, O, S, S$-donor ligands [22-28], etc., which can be designed to yield mononuclear or binuclear complexes or one-dimensional (1D), two-dimensional (2D) and three-dimensional (3D) metal-organic frameworks [29-36].

The synthesis and structural research of Schiff bases derived from the above mentioned aldehydes and amines bearing various alkyl and aryl $\mathrm{N}$-substituents, as well as their metal complexes have been of interest in our research group for over two decades [37-48].
Schiff base ligands may contain a variety of substituents with different electron-donating or electron-withdrawing groups, and therefore may have interesting chemical properties. They have attracted particular interest due to their biological activities [49-50], e.g. acting as radiopharmaceuticals for cancer targeting [51, 52]. They have also been used as model systems for biological macromolecules [53, 54]. Besides the biological activity, solid-state thermochromism and photochromism are an another characteristic of these compounds leading to their application in various areas of materials science such as the control and measurement of radiation intensity, display systems and optical memory devices [55-58]. Schiff bases derived from $o$-hydroxyaromatic aldehydes and ketones are excellent models for the study of ketoenol tautomerism both in solution and in the solid state [59-66]. During the past decade such Schiff bases started drawing attention due to their physical properties in the crystalline state [67-78]. These properties are greatly influenced by the topochemistry of the Schiff base molecules which in turn is highly affected by the crystal structure. Therefore the study of crystal packing and the intermolecular interactions in the crystal structures of various Schiff bases can lead to valuable data for the design and synthesis of new materials (Figure 1) [79-85].

\section{SCHIFF BASES IN THE CAMBRIDGE STRUCTURAL DATABASE (CSD)}

Searches to determine the number of CSD [10] entries for Schiff bases derived from hydroxyaryl aldehydes as well as for their complexes

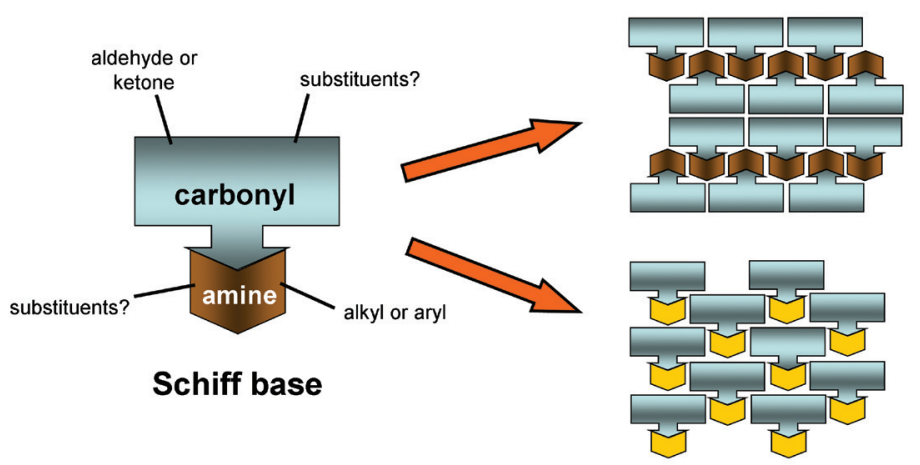

Fig. 1. Varying the type of amine (aliphatic or aromatic) and carbonyl (aldehyde or ketone) subunits, as well as substituents on them, a great number of Schiff bases with different supramolecular bonding capabilities can be prepared, which in turn enables great diversity of crystal packings 
<smiles>O=CC1=C(O)C=CCC1</smiles><smiles>O=Cc1cc2ccccc2cc1O</smiles><smiles>O=Cc1ccccc1O</smiles>
sal<smiles>COc1cccc(C=O)c1O</smiles><smiles>COc1cc(C=O)ccc1O</smiles>
van<smiles>CCOc1cccc(C=O)c1O</smiles>

etsal<smiles>O=Cc1ccc([N+](=O)[O-])cc1O</smiles>

nosal<smiles>O=Cc1cc(Cl)ccc1O</smiles>

clsal<smiles>O=Cc1ccc(O)c(C=O)c1</smiles>

brsal

Scheme 1. Molecular diagrams of 2-hydroxy-1-naphthaldehyde (napht), 3-hydroxy-2-naphthaldehyde (2napht), salicylaldehyde (sal), o-vanillin (ovan), vanillin (van), 3-ethoxysalicylaldehyde (etsal), 5-nitrosalicylaldehyde (nosal), 5-chlorosalicylaldehyde (clsal), 5-bromosalicylaldehyde (brsal)

were performed using ConQuest [86] version 5.31 with three updates (November 2009, February and May 2010). The data analysis was performed using the program Vista version 2.1 [87]. For free ligand the search criteria used were drawings of

Table 1

Number of unique structures in CSD for the selection of Schiff bases derived from nine different hydroxy aryl aldehydes

\begin{tabular}{lc}
\hline \hline Aldehyde & $\begin{array}{c}\text { Number of free } \\
\text { Schiff bases }\end{array}$ \\
\hline 2-hydroxy-1-naphthaldehyde & 68 \\
3-hydroxy-2-naphthaldehyde & 4 \\
salicylaldehyde & 199 \\
o-vanillin & 78 \\
vanillin & 10 \\
3-ethoxysalicylaldehyde & 12 \\
5-nitrosalicylaldehyde & 23 \\
5-chlorosalicylaldehyde & 37 \\
5-bromosalicylaldehyde & 42 \\
\hline \hline
\end{tabular}

the respective motifs of Schiff bases derived from nine different aldehydes: 2-hydroxy-1-naphthaldehyde (napht), 3-hydroxy-2-naphthaldehyde (2napht), salicylaldehyde (sal), $o$-vanillin (ovan), vanillin (van), 3-ethoxysalicylaldehyde (etsal), 5-nitrosalicylaldehyde (nosal), 5-chlorosalicylaldehyde (clsal), 5-bromosalicylaldehyde (brsal) (Scheme 1). Also, three filtering criteria were imposed upon the search: entries must have their 3-D coordinates determined, exhibit no errors and should have no transition metals present. Repeat determinations of the same structure, polymorphs and salts were removed from the count manually.

For Schiff base complexes the search criteria used were based on molecular diagrams involving any transition metal bonded to deprotonated hydroxyl oxygen and imine nitrogen of the respective deprotonated Schiff base. Also, searches to determine the number of entries for a particular metal $(\mathrm{Cu}, \mathrm{Ni}, \mathrm{Co}, \mathrm{V}, \mathrm{Fe}, \mathrm{Zn}, \mathrm{Mn})$ were performed. The analyses of entries for Schiff bases and their complexes are summarized in Table 1 and Table 2, respectively.

Tab 1 e 2

Number of CSD hits for hydroxyl aryl Schiff base complexes with transition metals (there are no entries corresponding to complexes of Schiff bases derived from vanillin and 3-hydroxy-2-naphthaldehyde)

\begin{tabular}{lcccccccc}
\hline \hline Aldehyde & $\begin{array}{c}\text { Number of } \\
\text { complexes }\end{array}$ & $\mathrm{Cu}$ & $\mathrm{Ni}$ & $\mathrm{Co}$ & $\mathrm{V}$ & $\mathrm{Fe}$ & $\mathrm{Zn}$ & $\mathrm{Mn}$ \\
\hline 2-hydroxy-1-naphthaldehyde & 237 & 83 & 42 & 12 & 24 & 12 & 18 & 17 \\
salicylaldehyde & 2616 & 674 & 342 & 215 & 168 & 275 & 162 & 345 \\
o-vanillin & 477 & 150 & 77 & 26 & 33 & 46 & 57 & 58 \\
3-ethoxysalicylaldehyde & 98 & 38 & 19 & 1 & 11 & 14 & 7 & 7 \\
5-nitrosalicylaldehyde & 114 & 33 & 15 & 8 & 3 & 11 & 17 & 16 \\
5-chlorosalicylaldehyde & 130 & 34 & 15 & 9 & 3 & 10 & 10 & 32 \\
5-bromosalicylaldehyde & 198 & 66 & 34 & 10 & 4 & 10 & 34 & 42 \\
\hline \hline
\end{tabular}


The search of the CSD revealed that during the last 50 years the Schiff bases of the salicylaldimine type, as well as their transition and inner transition metal complexes, have been studied more intensely than any other Schiff base derivative (Figure 2). It is remarkable that Schiff bases derived from salicylaldehyde make up $42 \%$ of the entire sample of studied Schiff bases and their complexes make up $68 \%$ of the entire sample of studied Schiff base complexes. As many as 199 entries for salicylaldehyde-based Schiff bases were found in the CSD [10]. Of these, 49 have been derived by condensation with aliphatic amines and 150 have been derived from aromatic amines. There are substantially less structural data on the Schiff bases derived from 2-hydroxy-1-naphthaldehyde with only 68 entries found for compounds of this type. Of these, 17 have been derived by condensation with aliphatic amines and 51 have been derived by using aromatic amines as condensation partners.

The distribution of the particular aldehyde type across the nine searched groups of Schiff bases (and complexes) in the CSD is shown graphically in Figure 3, as a percentage of the total number of entries obtained in this overview.
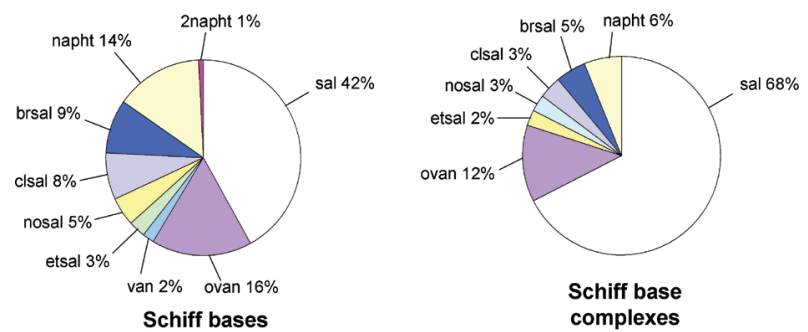

Fig. 3. The occurrence of Schiff bases derived from different aldehydes and their complexes in the CSD
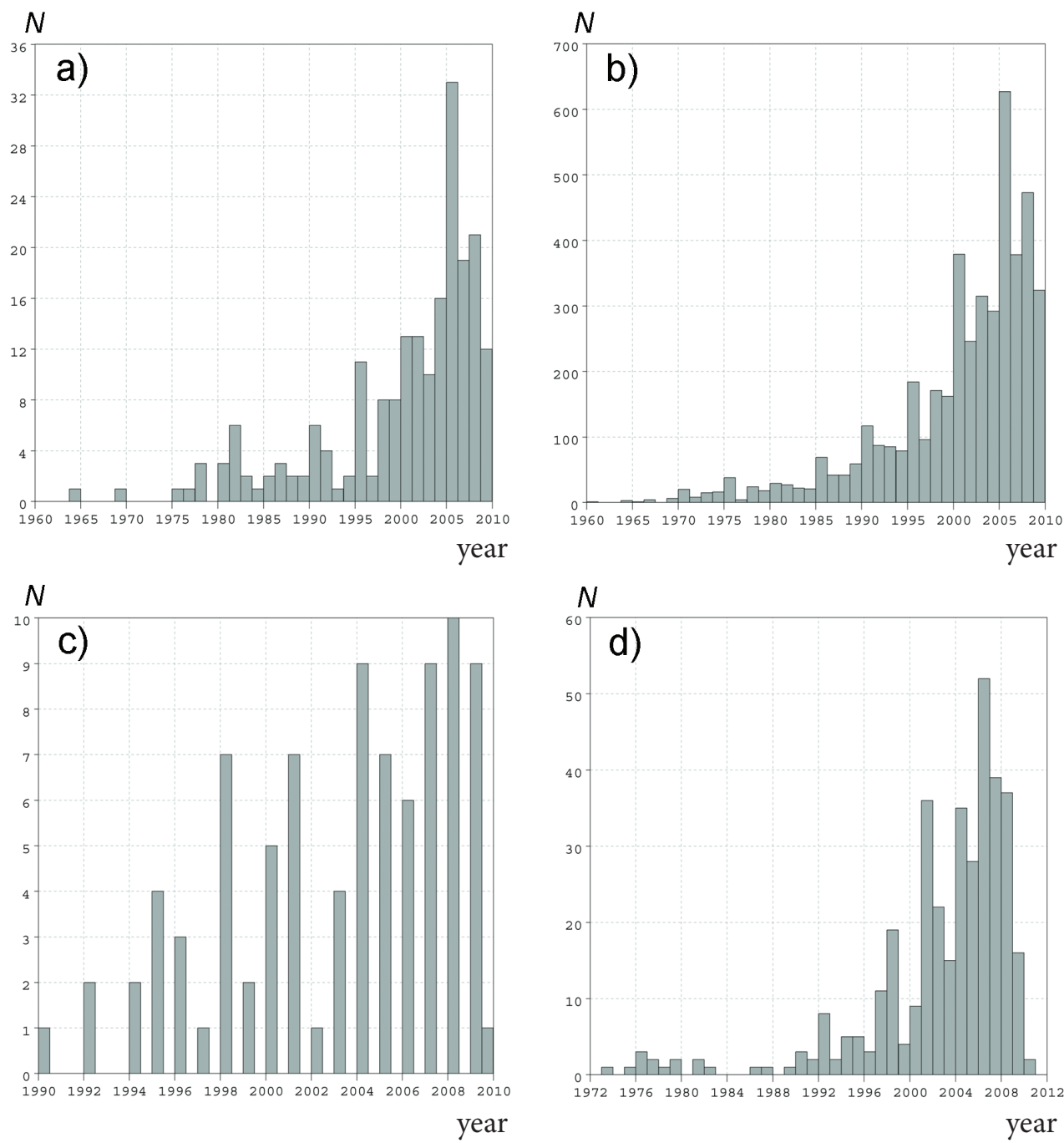

Fig. 2. Number of CSD entries per year for: a) Schiff bases derived from salicylaldehyde, b) coordination compounds with salicylaldimine Schiff bases, c) Schiff bases derived 2-hydroxy-1-naphthaldehyde and d) coordination compounds with naphthaldimine Schiff bases 
MOLECULAR STRUCTURE, INTRAMOLECULAR HYDROGEN BONDING, TAUTOMERISM AND QUINOID EFFECT

Aldimine compounds derived from the aromatic aldehydes having a hydroxyl group in the ortho position to the aldehyde group are of interest mainly due to the existence of either $\mathrm{O}-$ $\mathrm{H} \cdots \mathrm{N}$ or $\mathrm{O} \cdots \mathrm{H}-\mathrm{N}$ type of intramolecular hydrogen bond and the related tautomerism between such enol-imine and keto-amine forms. The presence of a particular tautomer in the crystal depends mostly on the parent $o$-hydroxyaryl aldehyde and the type of the $N$-substituent (i.e. aryl or alkyl). The electron withdrawing or donating ability of the $N$-substituents, their position and stereo chemistry, as well as hydrogen bond donor-acceptor properties, can stabilize one or another tautomer in the crystal. There does not seem to be any common relationship between molecular conformation and the sort of tautomer present in the crystalline state. During previous decades it was generally believed that the keto-amino naphthaldimines and salicylaldimines with the $N$-aryl substituent are planar and the enol-imino tautomers are nonplanar. However, this is not supported by currently available structural data which indicates the existence of non-planar keto-amino salicylaldimines as well as perfectly planar enolimino naphthaldimines with $\mathrm{N}$-aryl substituents (Figure 4) [10, 88-91].

The existence of the enol-imino tautomer has been established in most crystal structures of $\mathrm{N}$-substituted salycilaldimines listed in the CSD.
This is clearly represented by the distribution of $\mathrm{C}_{\mathrm{ar}}-\mathrm{O}$ bond lengths (Figure 5a), which makes it evident that 180 out of 199 entries $(90 \%)$ belong to the enol-imino and only 19 to the keto-amino tautomer. Unlike salicylaldimines, in naphthaldimines the keto-amino tautomer [46] appears somewhat prevalent over the enol-imino tautomer [31] (Figure 5b). The stabilization of the keto-amino tautomer in naphthaldimines is usually connected with the quinoid effect [92] since the structure of this tautomer is similar to that of $o$-naphthoquinone (Scheme 2). The presence of a fused aromatic ring stabilizes the quinoid ring and renders the geometry of the naphthalene moiety virtually independent on the position of the hydrogen atom along the $\mathrm{O} \cdots \mathrm{H} \cdots \mathrm{N}$ bond. Thus, the process of proton transfer from hydroxyl group to the imino nitrogen atom does not alter the approximate $D_{2 \mathrm{~h}}$ symmetry of the naphthalene moiety $[45,59]$.

Because of the ability of naphthaldimines to exist in both tautomeric forms, particular care must be taken when determining the molecular structures of such compounds in the crystalline state. It has been noted [31, 45, 80, 93] that, together with locating the hydrogen atom from an electron density difference map, the authors must also take molecular geometry (i.e. bond lengths, Figure 6) into account. Unfortunately, very often this does not seem to be the case. In the literature one can notice two main types of reported structures, in which misinterpretation of structural data is likely. The first group (for example: [94, 95]), Figure 7a), consists of reports where the hydrogen atom is simply generated on the oxygen atom
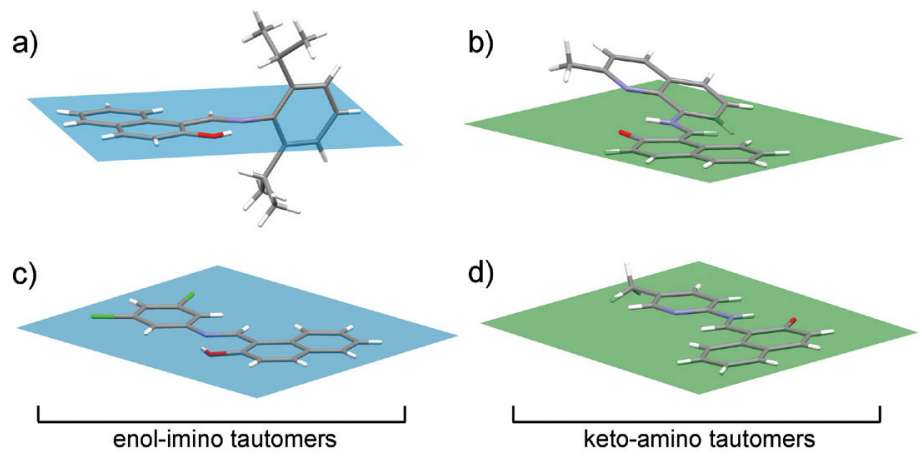

Fig. 4. Examples of planar and non-planar naphthaldimine Schiff bases with the $N$-aryl substituent: a) $N-(2,6-$ diisopropylphenyl)-2-hydroxy-1-naphthalideneamine [88], b) $N$-(2-methylquinon-8-yl)-1-aminomethylene-1Hnaphthalen-2-one [89] c) $N$-(3,5-dichlorophenyl)-2-hydroxy-1-naphthalideneamine [90] d) N-(5-pyridin-2-yl)-1aminomethylene-1H-naphthalen-2-one [91] 

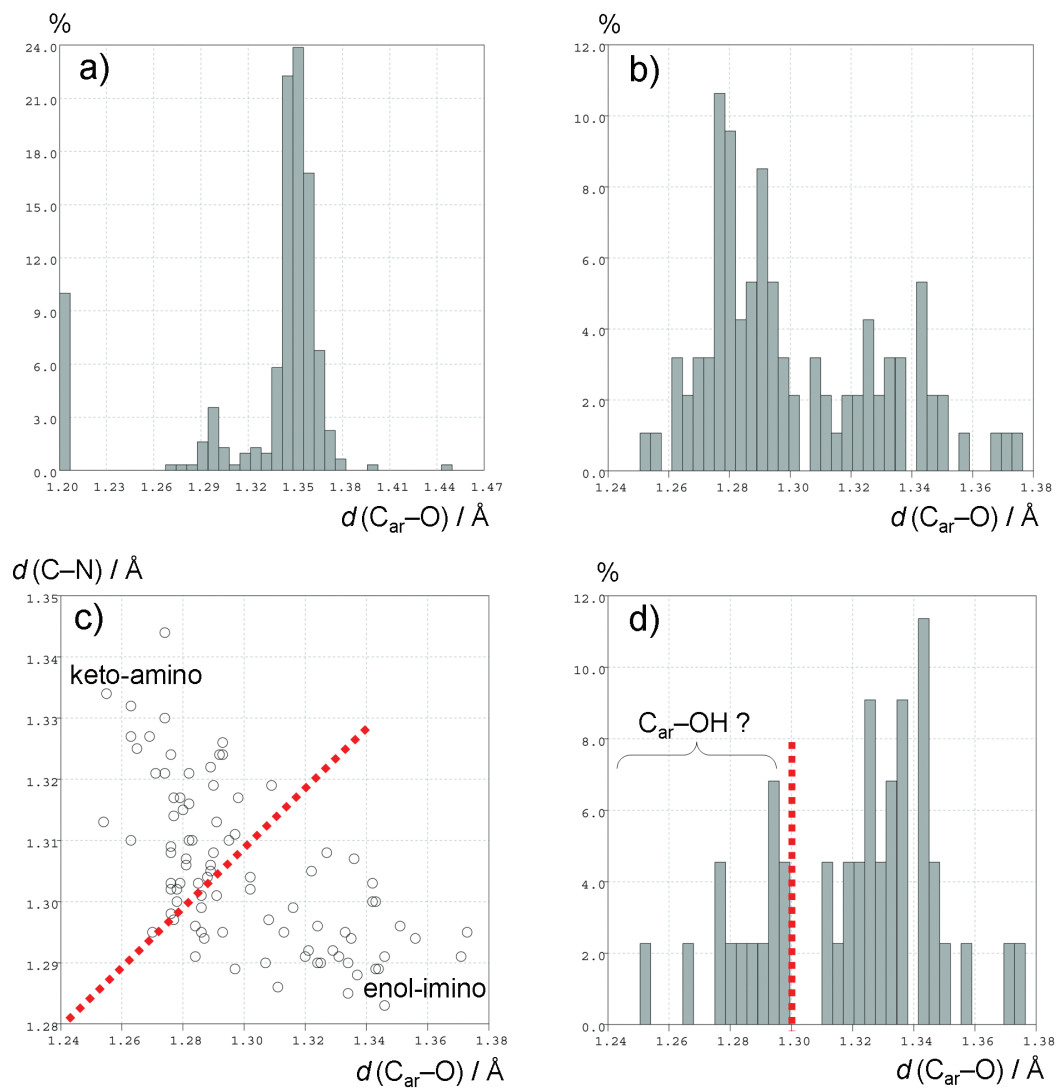

Fig. 5. a) The distribution of $\mathrm{C}_{\mathrm{ar}}-\mathrm{O}$ bond lengths of Schiff bases derived from salicylaldehyde, b) the distribution of $\mathrm{C}_{\mathrm{ar}}-\mathrm{O}$ bond lengths of Schiff bases derived from 2-hydroxy-1-naphthaldehyde, c) scattergram of $\mathrm{C}-\mathrm{N}$ and $\mathrm{C}_{\mathrm{ar}}-\mathrm{O}$ bond lengths of Schiff bases derived from 2-hydroxy-1-naphthaldehyde, and d) the distribution of $\mathrm{C}_{\mathrm{ar}}-\mathrm{O}$ bond lengths of Schiff bases derived from 2-hydroxy-1-naphthaldehyde deposited in the CSD as enol-imino tautomers (bond lengths shown left from dotted line clearly belong to $\mathrm{C}=\mathrm{O}$ double bonds indicating that they belong to keto-amino rather than enol-imino tautomers)

(probably because a hydroxyaldehyde was a starting compound) instead of being located from the electron difference map. This can, if the molecule is actually a keto-amine tautomer, lead to a structural model with a misplaced hydrogen atom and thus to a misinterpretation of the structure as an enol-imino tautomer. In the second group (for example: [91, 96, 97]), Figure 7b), the hydro- gen atom was located from the difference map on the nitrogen atom, but the bond lengths were not taken into account when assigning the bond type (single or double) and thus in some cases of keto-amine tautomers instead of the quinoid form the benzenoid form was used. Because of this, the nitrogen atom seems to be positively and the oxygen atom negatively charged, and the struc-<smiles></smiles>

enol-imino tautomer

(benzenoid form)<smiles>[R]N1C=C2C=CC(=O)C(=C1)C2=C</smiles>

keto-amino tautomer

(quinoid form)

Scheme. 2. Keto-amino tautomerisation in naphthaldimines

a)
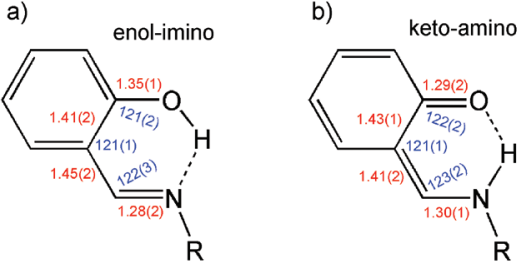

Schiff base c)

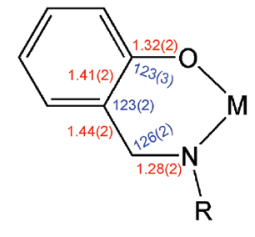

Schiff base complex

Fig. 6. Characteristic bond lengths (red) and angles (blue) for free Schiff bases derived from $o$-hydroxyaryl aldehydes and their complexes represented as average values for corresponding entries in the CSD: a) for enol-imino tautomer, b) for keto-amino tautomer, c) for a Schiff base coordinated to a metal ion.

All bond lengths are given in $\AA$ and angles in ${ }^{\circ}$ 

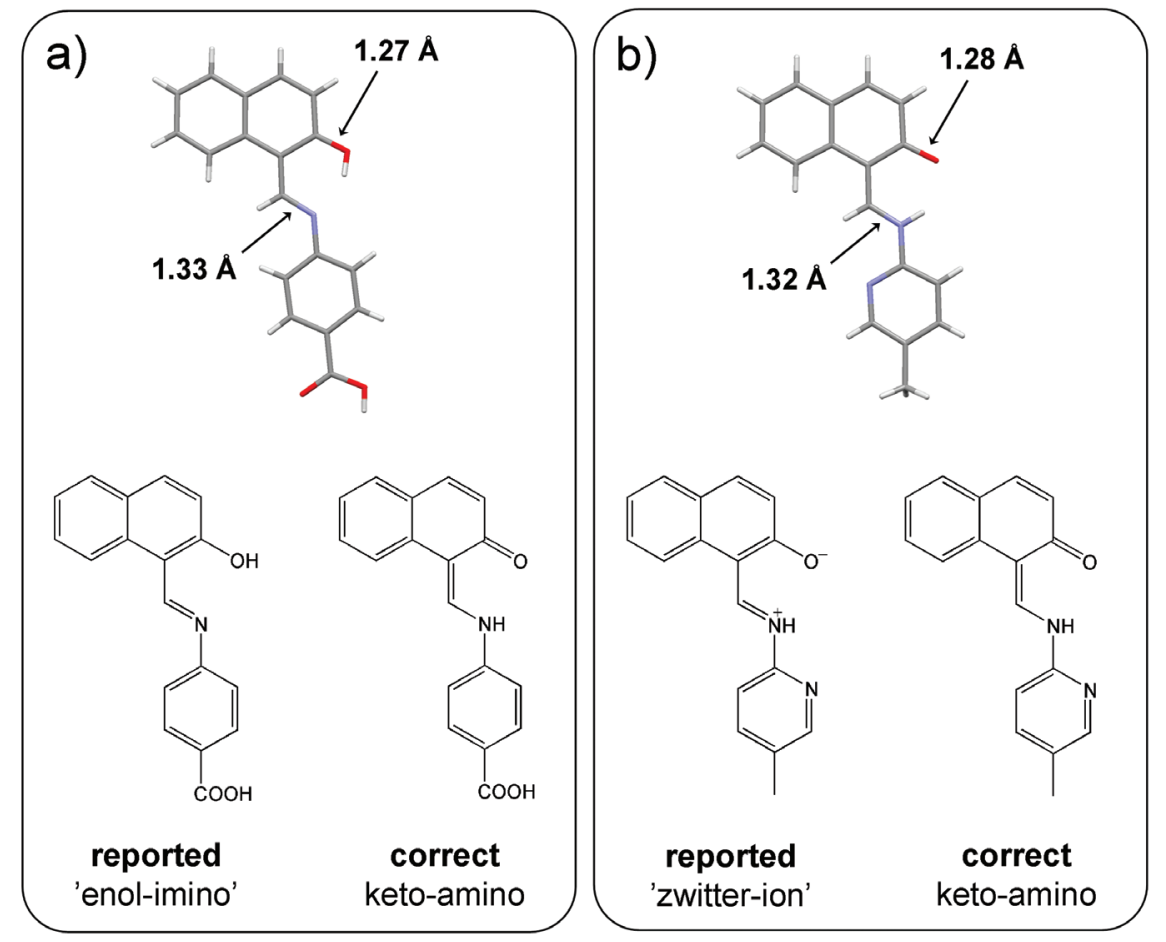

Fig. 7. Examples of two most common types of errors ensuing from the failure to detect the quinoid effect in naphthaldimines: a) 'enol-imino' [94] and b) 'zwitter-ion' [91]. In both cases the C-O bond lengths clearly indicate that $\mathrm{C}=\mathrm{O}$ is in fact a double bond, while the $\mathrm{C}-\mathrm{N}$ bond lengths show that $\mathrm{C}-\mathrm{N}$ bonds are single

tures are then reported as zwitter-ions instead of as keto-amine tautomers with no charge separation, which is a much more likely case.

The transfer of proton from hydroxyl oxygen atom of the parent aldehyde to the imino nitrogen atom in crystal state causes remarkable changes in the distribution of $\pi$-electrons and such changes are closely connected with physical properties in the crystalline Schiff bases, namely thermochromism and photochromism [56-58, 92, 98]. On the basis of structural studies of salicylaldimines, which are a well-known class of predominantly thermochromic compounds, it was established that these two effects are conformation-dependent. Non-planar molecules can exhibit photochromism, while planar molecules of this type Schiff bases exhibit thermochromism $[12,99]$.

\section{SUPRAMOLECULAR INTERACTIONS AND CRYSTAL PACKING}

Crystal packing in Schiff bases is determined by interactions between molecules which in turn are determined by functional groups available for forming interactions with neighbouring molecules (Figure 8). Although all the Schiff bases with aromatic $N$-substituent discussed in this review have the ability of forming intramolecular hydrogen bond, the central keto-amino moiety can interact with neighbouring molecules only if one of the subunits is not sterically demanding (as is the case in some Schiff bases with aliphatic $N$-substituent) [59, 94, 100].

Unless additional hydrogen bond donors and acceptors are present on the subunits themselves, the packing of the Schiff base will often be governed by weak interactions (dispersion forces, $\mathrm{C}-\mathrm{H} \cdots \pi$ hydrogen bonding, $\pi \cdots \pi$ stacking etc. [101-103]) alone. The presence of strong hydrogen bond donors and acceptors on the molecular periphery leads almost without exception to cross-linking of molecules via strong hydrogen bonds into dimers, oligomers, chains and other supramolecular assemblies. On the other hand if only additional hydrogen acceptors (usually $\mathrm{O}$ and $\mathrm{N}$ atoms), then $\mathrm{C}-\mathrm{H} \cdots \mathrm{O}$ and $\mathrm{C}-\mathrm{H} \cdots \mathrm{N}$ weak hydrogen bonds are usually the most important interactions between molecules.

$N$-(propyl)-1-aminomethylene-1H-naphthalen-2-one [59] (Figure 9), is an example of a Schiff base where the substituent on the imino nitrogen atom is the sterically non-demanding propyl group. The only noteworthy interaction 
a)<smiles>Oc1ccccc1/N=C/c1ccc(Br)cc1</smiles>

b)
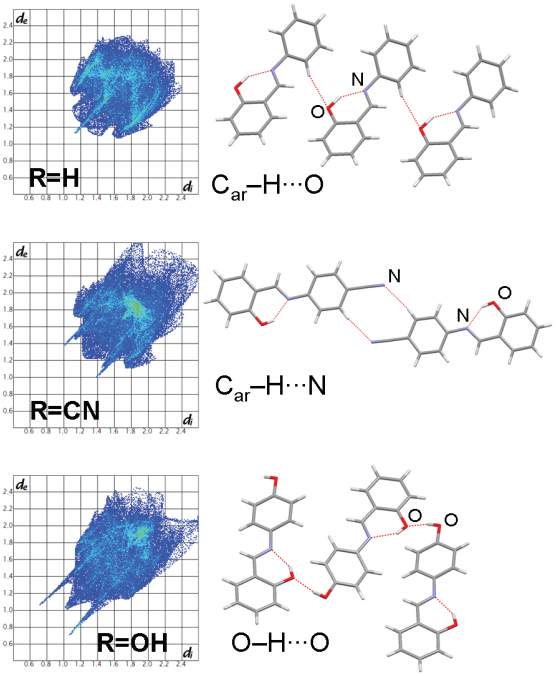
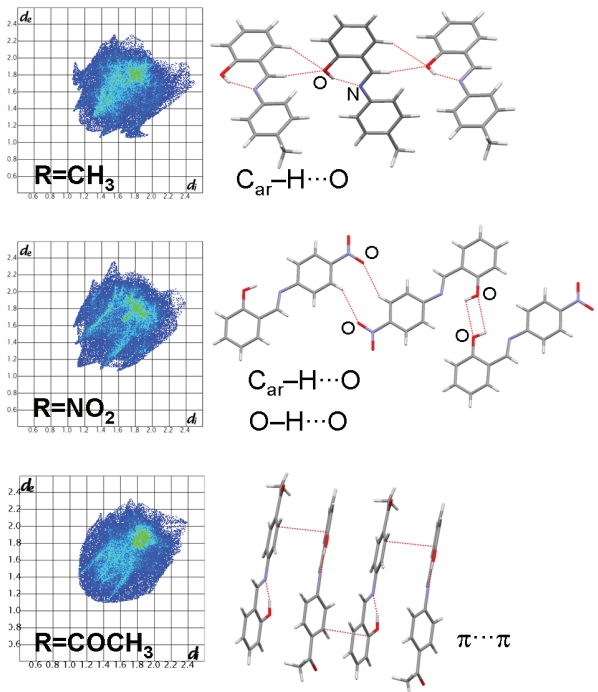

Fig. 8. a) Molecular diagram of a Schiff base derived from salicylaldehyde, b) two-dimensional fingerprint plots and fragments of packing for six Schiff bases with different substituent on $N$-substituted benzene ring: $N$-phenylsalicylideneamine [104], $N$-(4-cyanophenyl)salicylideneamine [105], $N$-(4-hydroxyphenyl)salicylideneamine [106], $N$-(4-methylphenyl)salicylideneamine [107], $N$-(4-nitroxyphenyl)salicylideneamine [108], $N$-(4-acetylphenyl) salicylideneamine [109]

a)<smiles>CCCN/C=C1\C(=O)C=Cc2ccccc21</smiles>

b)

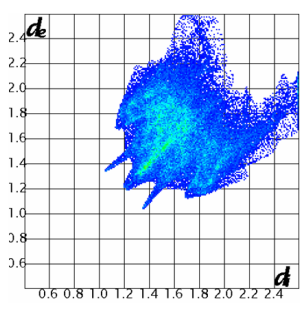

c)

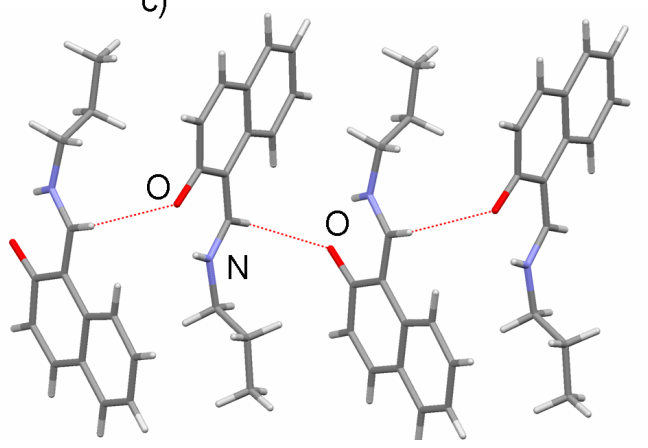

Fig. 9. a) Molecular diagram, b) two-dimensional fingerprint plot, and c) fragment of the chain in the crystal of $N$-(propyl)-1-aminomethylene- $1 H$-naphthalen-2-one

between molecules in the crystal structure is a weak $\mathrm{C}-\mathrm{H} \cdots \mathrm{O}$ interaction of $3.23 \AA$ between the imino methine and the oxygen atom of the central keto-amino group. The described interaction can be observed by close analysis of the two-dimensional fingerprint plot derived from the Hirshfeld surface [110] of the molecule. Similarly, in the crystal structure of $N, N^{\prime}$-hexylene-bis(1-aminomethylene- $1 H$-naphthalen2-one) [99], a bis Schiff base derived from naphthaldehyde and an aliphatic diamine, the keto oxygen atom is the hydrogen acceptor in $\mathrm{a} \mathrm{C}_{\mathrm{ar}}-\mathrm{H} \cdots \mathrm{O}$ interaction of $3.46 \AA$ leading to the formation of chains (Figure 10).

In the crystal structure of $N, N^{\prime}$-butylenebis(1-aminomethylene- $1 H$-naphthalen-2-one) [100] the central keto-imino groups of neighbouring molecules are sufficiently close to one another that an intermolecular $\mathrm{N}-\mathrm{H} \cdots \mathrm{O}$ hy- a)

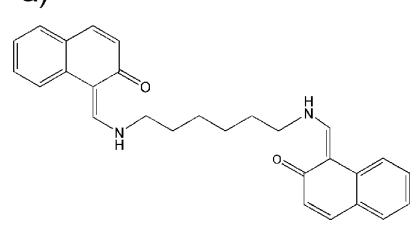

b)

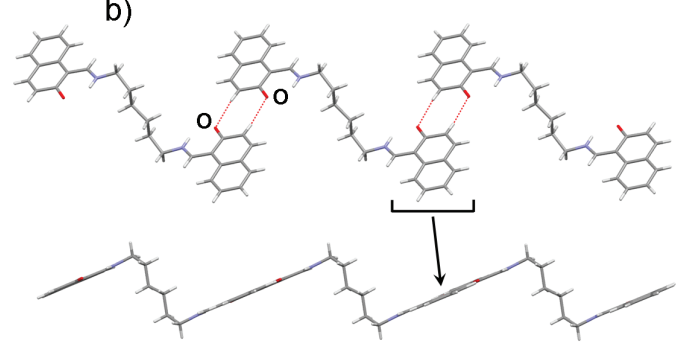

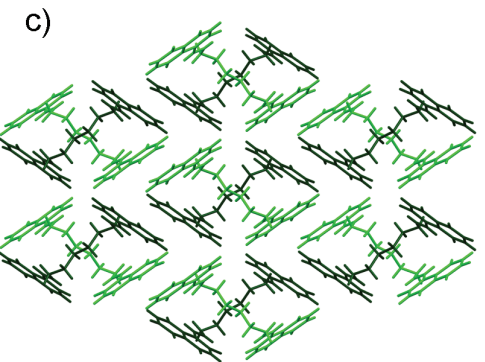

Fig. 10. a) Molecular diagram, b) fragment of the chain in the crystal, and c) view of the packing of molecules for $N, N$ '-hexylene-bis(1-aminomethylene-1H-naphthalen-2-one) [100] 

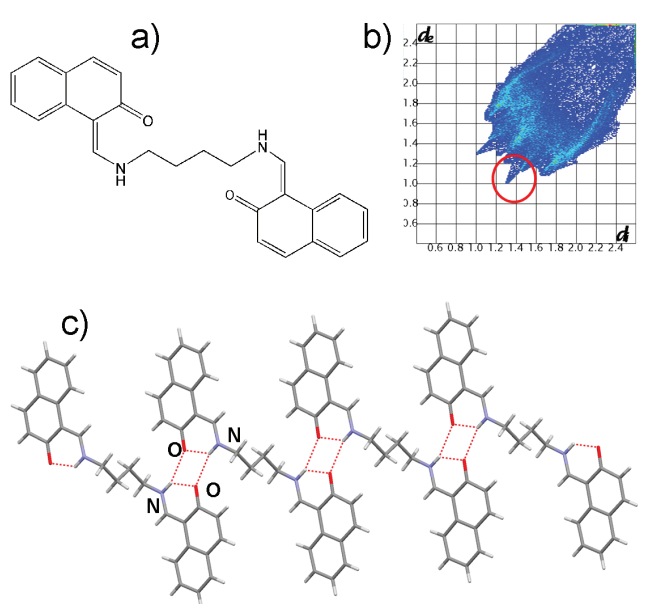

Fig. 11. a) Molecular diagram, b) two-dimensional fingerprint plot (marked corresponding region for $\mathrm{N}-\mathrm{H} \cdot \cdots \mathrm{O}$ hydrogen bond), and c) a fragment of the hydrogen-bonded chain in the crystal of $N, N$ '-butylene-

bis(1-aminomethylene- $1 H$-naphthalen-2-one) [100]

drogen bond is formed. Each amino hydrogen atom participates in an intramolecular (2.59 $\AA$ ) and a somewhat longer intermolecular hydrogen bond $(2.98 \AA)$. This bonding results in the formation of chains in the crystal structure (Figure 11) and is reflected in a considerably higher melting point.

If an additional hydrogen donor is present, providing the $N$-substituent is sufficiently small, it can form a hydrogen bond with the keto-amino oxygen atom. This occurs in the crystal structure of $\mathrm{N}$-(2-hydroxyethyl)-1-aminomethylene- $1 \mathrm{H}$ naphthalen-2-one [43] where the $N$-substituent is a primary alcohol which acts as a hydrogen donor forming a $\mathrm{O}-\mathrm{H} \cdot \cdots \mathrm{O}$ intermolecular hydrogen bond of $2.71 \AA$ with the keto-amino oxygen atom forming dimers. The dimers in the crystal structure are further linked via weak $\mathrm{C}_{\mathrm{ar}}-\mathrm{H} \cdots \mathrm{O}$ contacts generating a 3D-network (Figure 12).

Unlike Schiff bases derived from $o$-hydroxyaromatic aldehydes, those derived from $m$ - and $p$-hydroxyaromatic aldehydes will not be able to form an intramolecular hydrogen bond as described above. Instead, a free hydrogen bond donor (hydroxyl group) and an acceptor (imino group) are available for intermolecular hydrogen bonding. This can be observed in the structure of $\mathrm{N}$-(4-methylphenyl)-hydroxy3-methoxybenzilideneamine [111] where intermolecular $\mathrm{O}-\mathrm{H} \cdots \mathrm{N}$ hydrogen bonds of $2.84 \AA$ connect the molecules into chains (Figure 13).

Increasing the size of the $N$-substituent a)
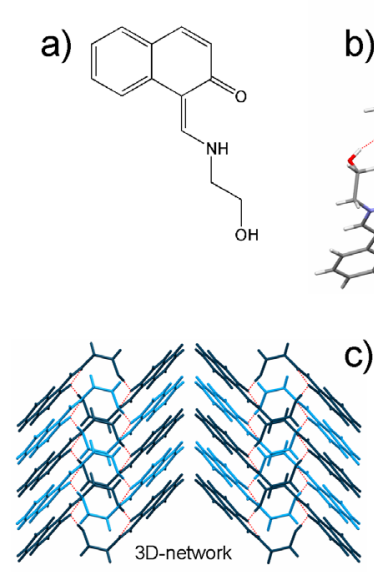

c)

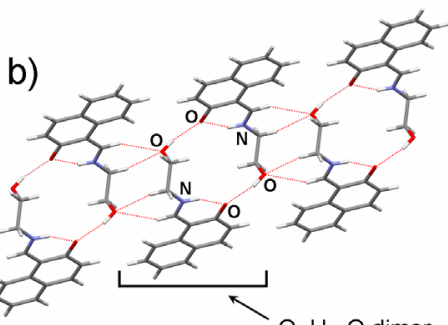

)

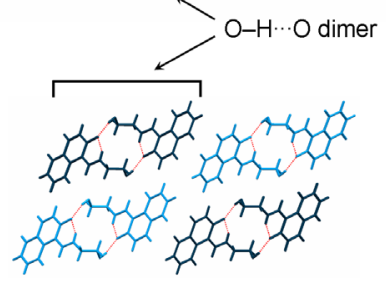

Fig. 12. a) Molecular diagram, b) fragment of the chain in the crystal, and c) view of the packing of molecules for $\mathrm{N}$-(2-hydroxyethyl)-1-aminomethylene-1 $H$-naphthalen2-one [43] a)

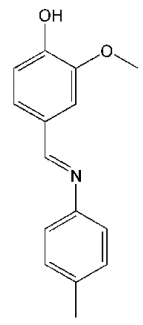

b)

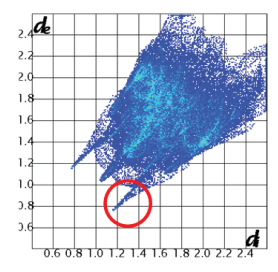

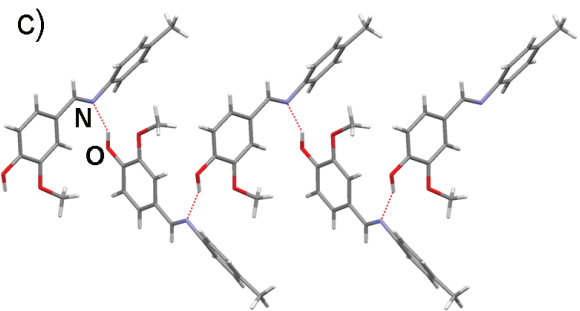

Fig. 13. a) Molecular diagram, b) two-dimensional fingerprint plot (marked corresponding region for $\mathrm{O}-\mathrm{H} \cdots \mathrm{N}$ hydrogen bond), and c) a fragment of the hydrogen-bonded chain in the crystal of $\mathrm{N}$-(4methylphenyl)-hydroxy-3-methoxybenzilideneamine

[111]

renders the participation of hydrogen donors and acceptors of the central keto-amino group in intermolecular bonding less probable. In such cases, and if additional hydrogen donors and acceptors are absent, the packing is governed by weak interactions. Two Schiff bases, namely $N-(\alpha-$ naphthyl)-1-aminomethylene-1H-naphthalen-2one and $\mathrm{N}$-( $\beta$-naphthyl)-1-aminomethylene- $1 \mathrm{H}$ naphthalen-2-one, differ only in the spatial orientation of $N$-naphthyl group with regard to the 2-oxy-1-naphthaldeimine [59]. Both molecules show a high degree of planarity with essentially identical interplanar twist angles between the $N$ substituents and the rest of the molecule. Because 
a)
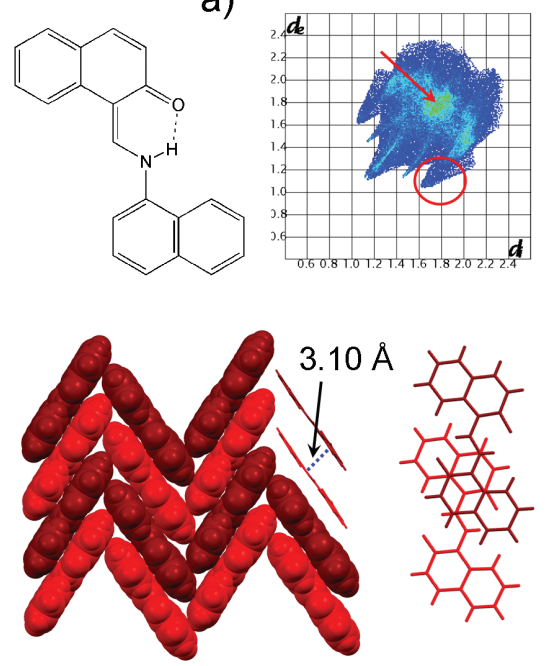

b)
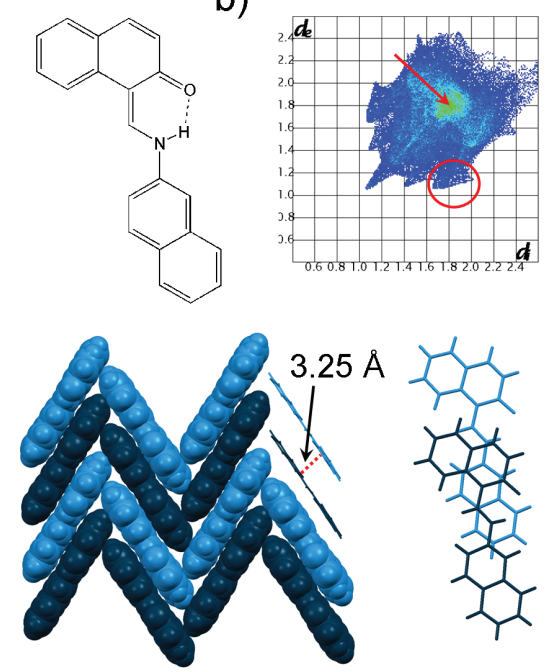

Fig. 14. Molecular diagram, two-dimensional fingerprint plot (marked corresponding regions: red arrow for $\pi \cdots \pi$ contacts and red circle for $\mathrm{C}-\mathrm{H} \cdots \pi$ contacts) and view of the packing and $\pi-\pi$ stacking for compounds:

a) $N$-( $\alpha$-naphthyl)-1-aminomethylene-1 $H$-naphthalen-2-one, b) $N$-( $\beta$-naphthyl)-1-aminomethylene-1 $H$-naphthalen-2-one [59]

of the lack of hydrogen-bonding functionalities on the $N$-substituents, all interactions between neighbouring molecules in both compounds are on the basis of the weak intermolecular contacts. The discrete molecules are stacked to give a $\pi$-stacked chains. The adjacent chains are further linked via weak $\mathrm{C}-\mathrm{H} \cdots \pi$ contacts contacts and generate a herringbone motif (Figure 14).

Crystal structures of Schiff bases derived from aldehydes and amines which have additional groups containing non-bonding electron pairs (alkoxy, acyl, nitro, cyano, pyridine etc.) which may act as hydrogen bond acceptors are often directed by weak hydrogen bonds formed between such groups and aromatic hydrogen donors. An example of such intermolecular bonding can be seen in the crystal structure of $\mathrm{N}$-(2-pyridyl)-3-methoxysalicylideneamine [112] (Figure 15a), where methoxy oxygen and pyridine nitrogen atoms participate as acceptors of intermolecular hydrogen bonds. The crystal structure comprises of $\mathrm{C}_{\mathrm{ar}}-\mathrm{H} \cdots \mathrm{O}$ hydrogenbonded dimers (Figure 15b), which are linked via another set of weak $\mathrm{C}-\mathrm{H} \cdots \mathrm{O}$ interactions into a 2D-network. The layers are further interconnected by $\mathrm{C}-\mathrm{H} \cdots \mathrm{N}$ interactions between imino methine group and pyridine nitrogen with $\mathrm{C} \cdots \mathrm{N}$ distances of $3.62 \AA$, which is comparable with $\mathrm{C}-\mathrm{H} \cdots \mathrm{N}$ intermolecular bonding in other Schiff bases derived from pyridylamines [113].

$\mathrm{C}-\mathrm{H} \cdots \mathrm{N}$ intermolecular bonding frequently occurs in crystal structures of Schiff bases derived from aminonitriles. Figure 16 depicts hydrogen bonding motifs in Schiff bases derived from naphthaldehyde and 2-, 3- and 4-aminobenzonitrile demonstrating the effect of the position of the cyano group on the crystal packing [114-116]. In the case of the 3-aminobenzonitrile derivative, a combination of $\mathrm{C}_{\mathrm{ar}}-\mathrm{H} \cdots \mathrm{N}$ and $\mathrm{C}_{\mathrm{ar}}-\mathrm{H} \cdots \mathrm{O}$ interactions results in the formation of molecular chains (Figure 16b). In 2-aminobenzonitrile derivative, due to different directionality a)

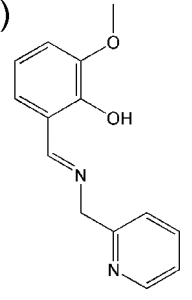

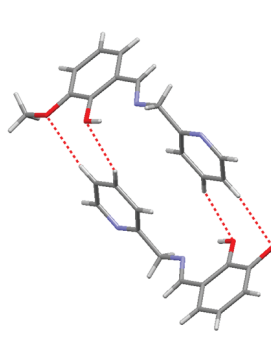

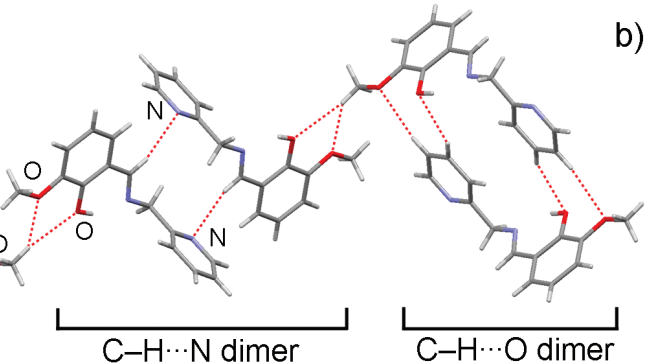

b)

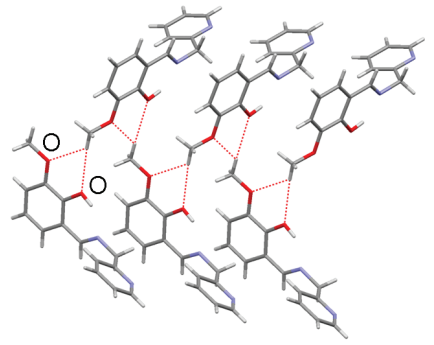

Fig. 15. a) Molecular diagram, b) fragments of packing in the crystal of $N$-(2-pyridyl)-3-methoxysalicylideneamine [112] 

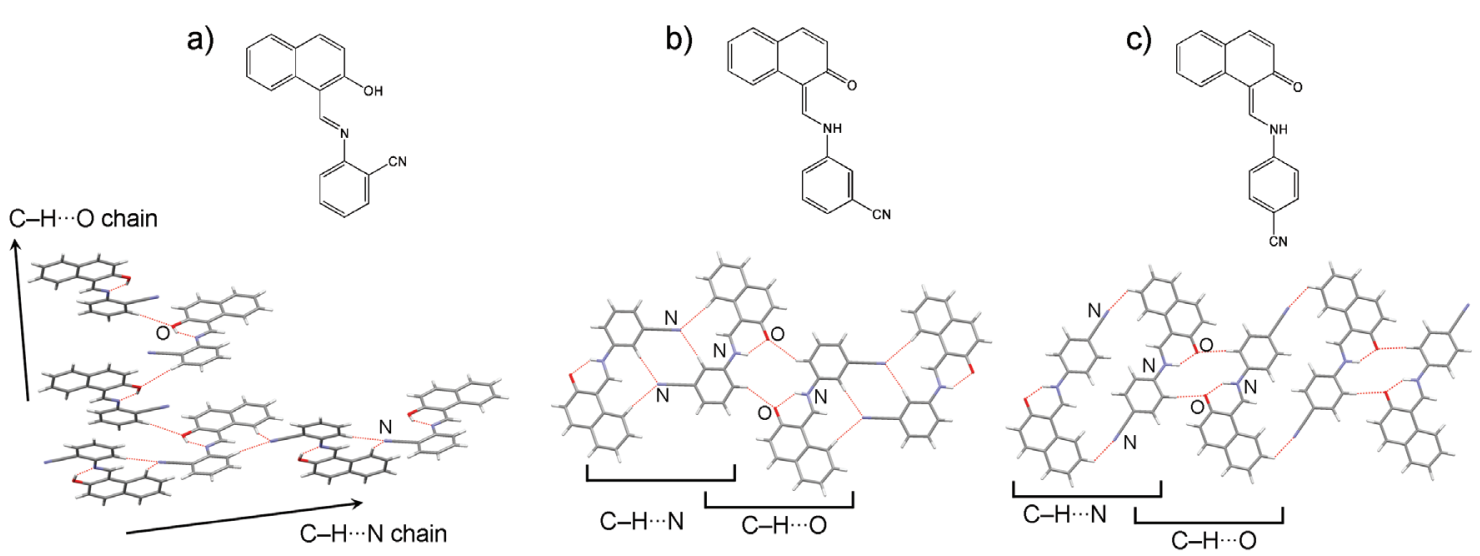

Fig. 16. Molecular diagram and fragment of the chain in the crystal for compounds: a) $N$-(2-cyanophenyl)-2-hydroxy-1naphthalideneamine [114], b) $N$-(3-cyanophenyl)-1-aminomethylene-1H-naphthalen-2-one [115],

c) $N$-(4-cyanophenyl)-1-aminomethylene-1H-naphthalen-2-one [116]

of the cyano group, the hydrogen bond involving the same donor/acceptor set results in a different supramolecular topology. The molecules are connected into chains via $\mathrm{C}_{\mathrm{ar}}-\mathrm{H} \cdots \mathrm{N}$ interactions and the chains are further connected by $\mathrm{C}_{\mathrm{ar}}-\mathrm{H} \cdots \mathrm{O}$ interactions into layers (Figure 16a). A different type of supramolecular topology is observed in the crystal structure of the 4-aminobenzonitrile derivative, where $\mathrm{C}_{\mathrm{ar}}-\mathrm{H} \cdots \mathrm{N}$ and $\mathrm{C}_{\mathrm{ar}}-\mathrm{H} \cdots \mathrm{O}$ interactions leads to a 3D-network (Figure 16c).

In the crystal structures of Schiff bases with carboxyl substituents the formation of strong hydrogen bonds is expected, with the carboxyl group acting as the hydrogen donor and

a)
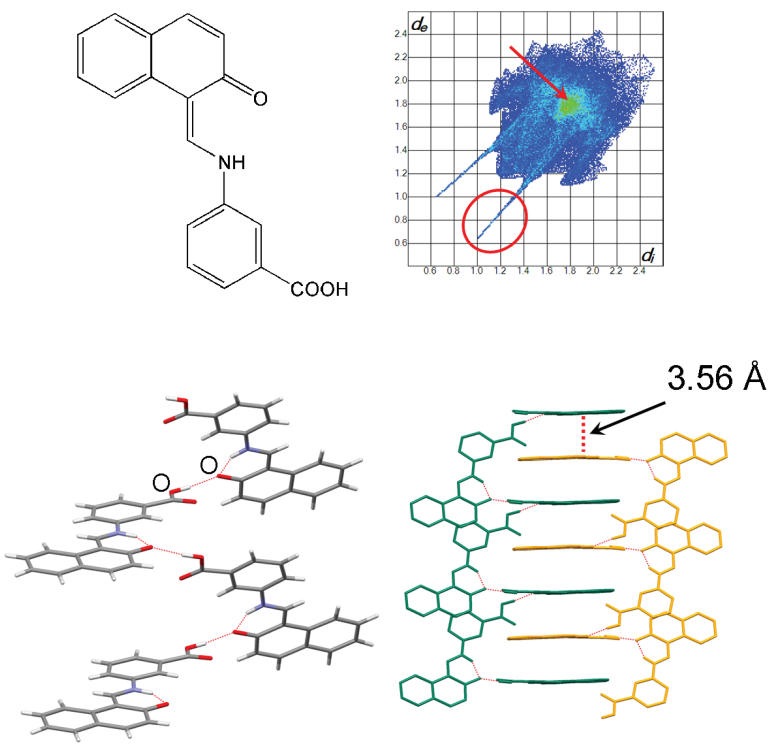

either carboxyl group or the central keto-amino group acts as hydrogen acceptors. Both cases are illustrated by Schiff bases derived from 2-hydroxy-1-naphthaldehyde and different aminobenzoic acids (Figure 17). In the crystal structure of $\mathrm{N}$-(3-carboxyphenyl)-1-aminomethylene- $1 \mathrm{H}$ naphthalen-2-one [94] (Figure 17a) the hydrogen bond acceptor is the keto-amino oxygen atom and hydrogen bonding leads to chains, while in the structure of $\mathrm{N}$-(4-carboxyphenyl)-1-aminomethylene-1H-naphthalen-2-one [117] (Figure $17 \mathrm{~b})$ the hydrogen bond acceptor is the carboxyl group which results in the formation of characteristic carboxyl dimers.

b)
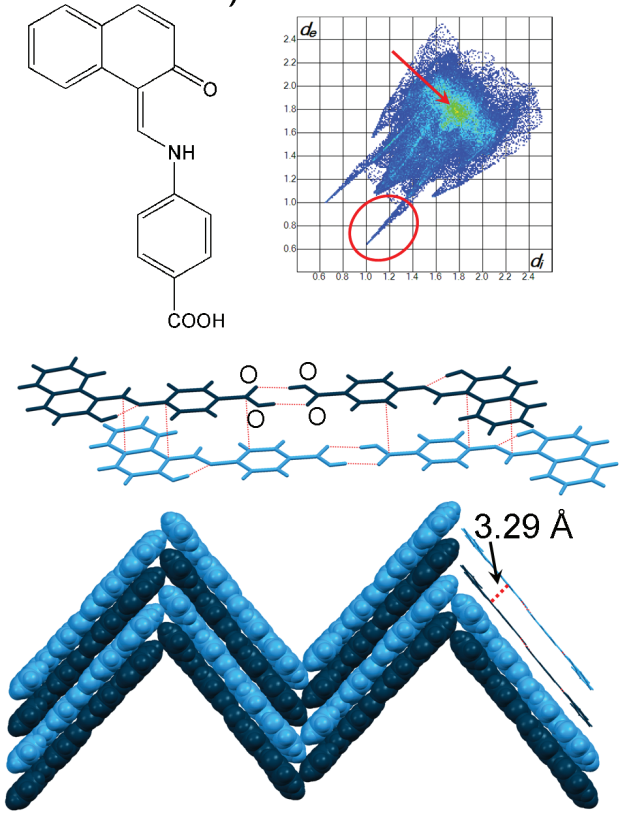

Fig. 17. Molecular diagram, two-dimensional fingerprint plot (marked corresponding regions: red arrow for $\pi \cdots \pi$ contacts and red circle for $\mathrm{O}-\mathrm{H} \cdots \mathrm{O}$ hydrogen bond) and view of the packing and $\pi \cdots \pi$ stacking for compounds:

a) $N$-(3-carboxyphenyl)-1-aminomethylene-1H-naphthalen-2-one [94], and

b) $\mathrm{N}$-(4-carboxyphenyl)-1-aminomethylene-1 $H$-naphthalen-2-one [113] 


\section{METAL COMPLEXES OF SCHIFF BASES}

Replacing the hydrogen atom from the intramolecular hydrogen bond in the salicylaldimine and naphthaldimine Schiff bases by a metal ion, can have a significant influence on the geometry of the molecule [31]. The main structural feature distinguishing the free Schiff base from the coordinated ligand appears in: (i) a large difference in the $\mathrm{O} \cdots \mathrm{N}$ separation, the so called 'bite' distance of the chelate ligand; ii) changes in bond distances and angles in what becomes a chelate ring (Figure 6c) which is associated with the re-distribution of $\pi$-electrons (pseudoaromaticity), and iii) a significant change in the spatial orientation of the $N$-substituent (Figure18).

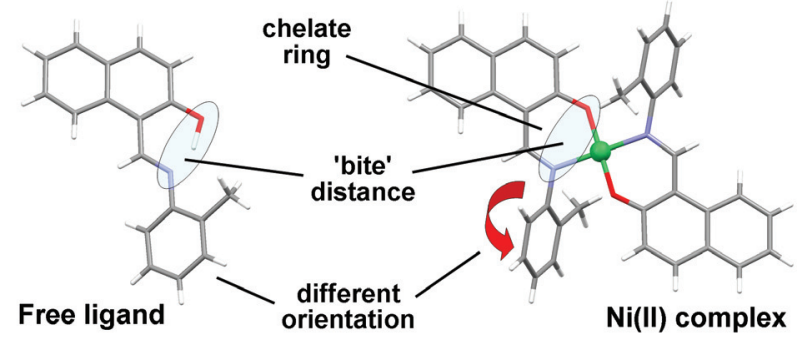

Fig. 18. Representation of conformational differences between free Schiff bases and Schiff bases bonded to metal ions

The distribution of $\mathrm{O} \cdots \mathrm{N}$ "bite" distances for free Schiff bases and their complexes is shown in Figure 19. The distance increases upon the binding of the metal ion, the average bite distance rising from 2.59(5) $\AA$ in free Schiff bases to 2.79(6) $\AA$ in complexes. Such behaviour which is to be expected since the metal ion replaces a much smaller hydrogen. Consequently, the bite distance of a Schiff base in a complex is very dependent on the metal atom. The average bite distance in complexes of $\mathrm{Cu}(\mathrm{II})$ is 2.80 (3) $\AA$, in $\mathrm{Co}(\mathrm{II})$ complexes $2.78(6)$ $\AA$, 2.72(6) $\AA$ in V(III) complexes, 2.78(4) $\AA$ in $\mathrm{Fe}(\mathrm{II})$ complexes, 2.88(5) $\AA$ in $\mathrm{Zn}$ (II) complexes and 2.77(2) $\AA$ in Mn(II) complexes. The bite distance is also noticeably affected by the coordination of the metal ion - the average bite distance in tetracoordinated $\mathrm{Ni}$ (II) complexes is 2.72(3) $\AA$ and in hexacoordinated 2.87(3) $\AA$.

In the complex chelate ring of bis $(\mathrm{N}-(2-$ methylphenyl)-2-hydroxy-1-naphthalidenato)
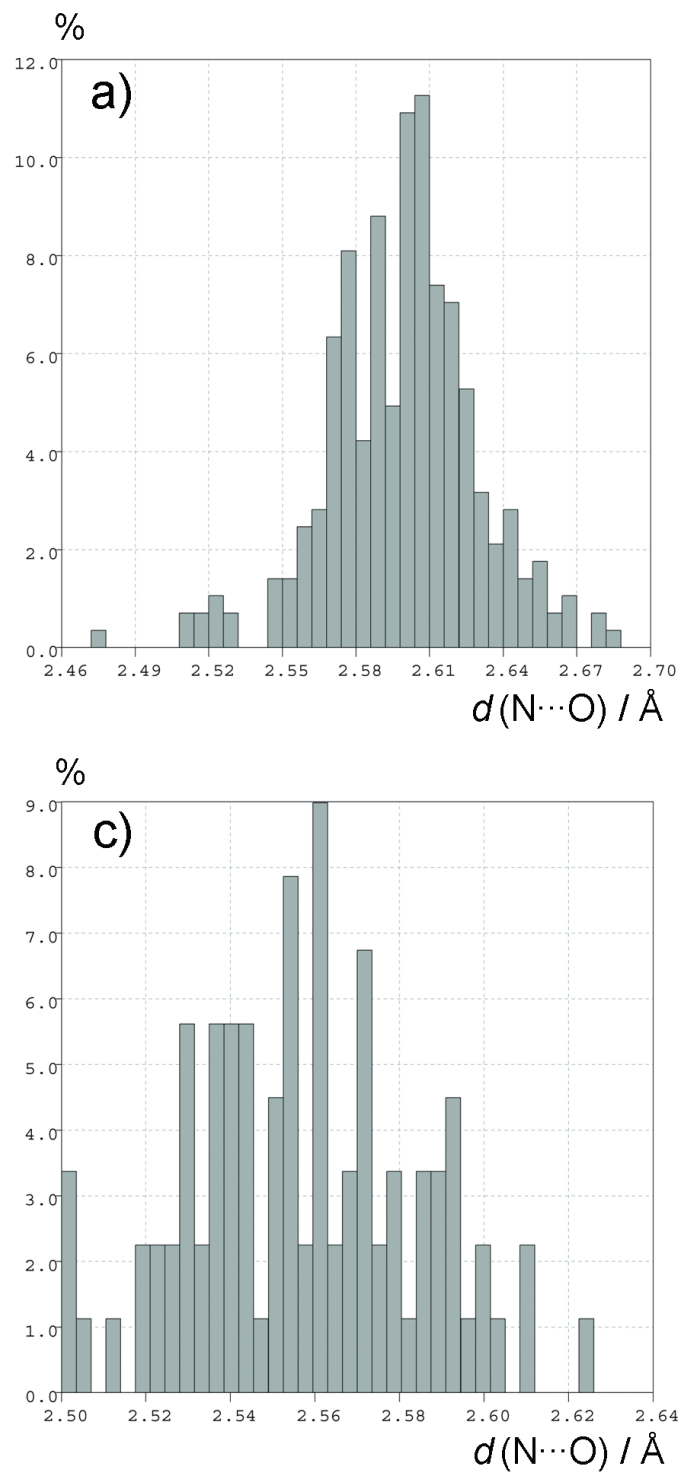

$d(\mathrm{C}-\mathrm{N}) / \AA$

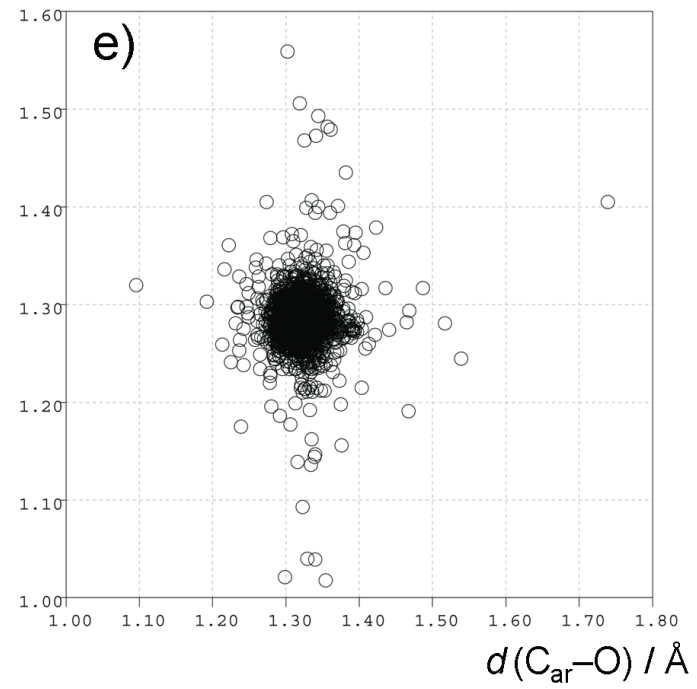

Fig. 19. a) The distribution of $\mathrm{N} \cdots \mathrm{O}$ bite distance of Schiff bases derived from salicylaldehide, and $b$ ) their complexes c) The distribution of $\mathrm{N} \cdots \mathrm{O}$ bite distance of Schiff bases derived from 2-hydroxy-1- 

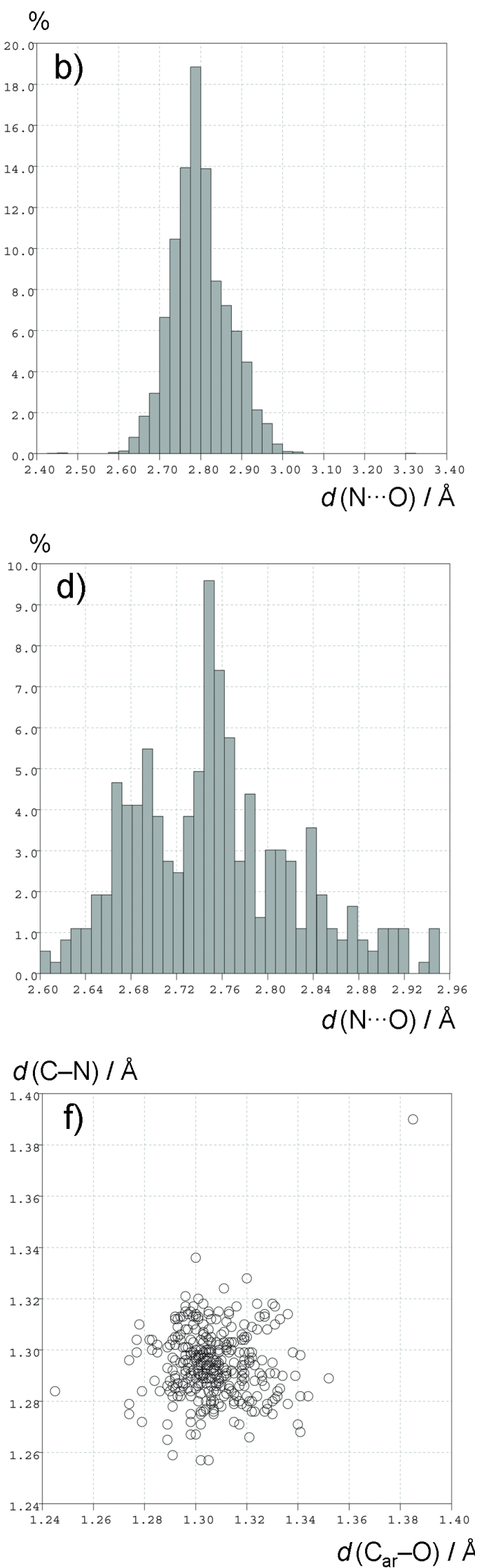

naphthaldehyde, d) and their complexes e) The plot of $\mathrm{C}-\mathrm{N}$ vs. $\mathrm{C}_{\mathrm{ar}}-\mathrm{O}$ bond lenghts of Schiff base complexes derived from salicylaldehyde, and f) 2-hydroxy-1naphthaldehyde
nickel(II) [31] there is a general tendency of shortening the $\mathrm{O}-\mathrm{C}$ and $\mathrm{C}-\mathrm{C}$, and lengthening of the $\mathrm{N}-\mathrm{C}$ bond distances in comparison to the corresponding bonds in the free Schiff base ligand. The naphthaldimine moiety in the complex exhibits the quinoidal bond lengths assembly. The ligand itself is not planar, due to the twist of the $o$-tolyl ring connected on the amino nitrogen out of the naphthalene moiety plane with the corresponding dihedral angles $\mathrm{ca} 53.0^{\circ}$ and $40.2^{\circ}$ for free and coordinated molecule, respectively (Figure 20). The twisting of the $o$-tolyl moiety is affected by the molecular environment and packing in the crystal, as a consequence of sterical hindrance due to the approaching of two ligands to each other in the complex and the increase of bond angles in the chelate ring. Similar stereochemical behaviour was observed in the analogous nickel(II) complexes with $\mathrm{N}$-(2,6-diisopropylphenyl)- [118] and $N$-( $\beta$-naphthyl)-2hydroxy-1-naphthalidenamine [119]. a)

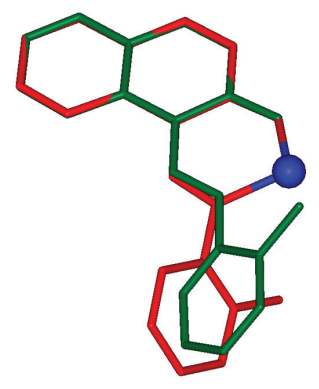

b)

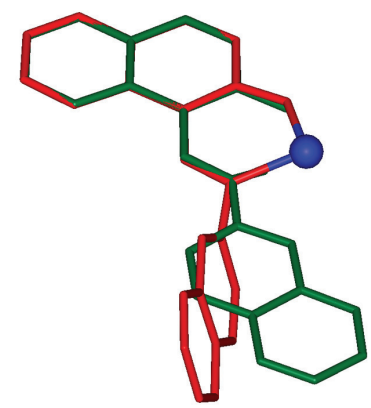

Fig. 20. Overlap of free Schiff base (red) and a Schiff base coordinated to nickel(II) (green), a) $\mathrm{N}$-(2methylphenyl)-2-hydroxy-1-naphthalidenamine [31],

b) $N$-( $\beta$-naphthyl)-2-oxy-1- naphthalidenamine [119]. The fragments are fitted by best overlap of 10 naphthalene atoms

As noted earlier, there has been continuous interest in the coordination compounds of $\mathrm{Cu}(\mathrm{II})$ and $\mathrm{Ni}(\mathrm{II})$, and to a somewhat lesser degree of Co(II), with Schiff bases derived from salicyl- and naphthaldehydes. This is mostly due to the variability of the geometric features of the coordination sphere around the metal which can range from square planar to deformed tetrahedral geometry [120-122]. In most complexes both electronic effect [123, 124] and crystal packing $[125,126]$ have been invoked as the driving forces responsible for the distortion. 
However, a significant role in the coordination geometry of the ligands around the metal atom is played by the nature and volume of the $\mathrm{N}$ substituent and intermolecular interactions, i.e. crystal packing forces.

A simple measure of the coordination polyhedron geometry for bis(bidentate Schiff base) coordination compounds is the $d_{\mathrm{NN}} / d_{\mathrm{NO}}$ ratio $i$. e. the ratio of distances from one donor atom (e.g. $\mathrm{N}$ ) of one ligand to the equivalent $(\mathrm{N})$ and to the non-equivalent $(\mathrm{O})$ donor atom of the other ligand (Figure 21a). For trans-planar expected value of this ratio is $d_{\mathrm{NN}} / d_{\mathrm{NO}} \approx \sqrt{2}\left(d_{\mathrm{NN}}\right.$ $/ d_{\mathrm{NO}}=\sqrt{2}$ for a perfect square and $d_{\mathrm{NN}} / d_{\mathrm{NO}}>$ $\sqrt{2}$ in most real complexes), for tetrahedral $d_{\mathrm{NN}}$

$/ d_{\mathrm{NO}} \approx 1$ and for cis-planar $d_{\mathrm{NN}} / d_{\mathrm{NO}} \approx \sqrt{ } 2 / 2$. $d_{\mathrm{NN}} / d_{\mathrm{NO}}$ plots for mononuclear bis(bidentate Schiff base) complexes of tetracoordinated nickel(II), cobalt(II) and copper(II) are given in Figure 21 and show distribution of data points into regions corresponding to above mentioned coordination geometries.

In the case of nickel complexes there is an extreme tendency towards trans-planar coordination with only several examples of tetrahedral complexes (Figure 21b). The trans-planar nickel(II) complexes are usually negligibly tet- a)
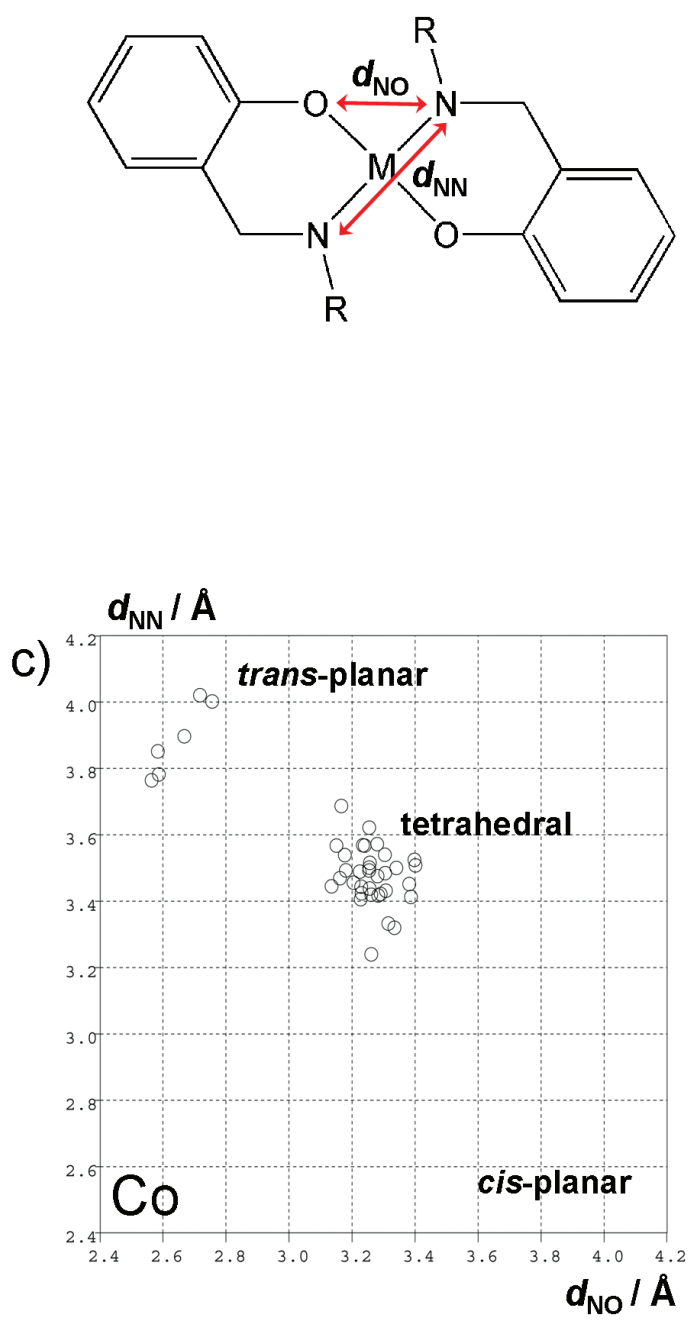
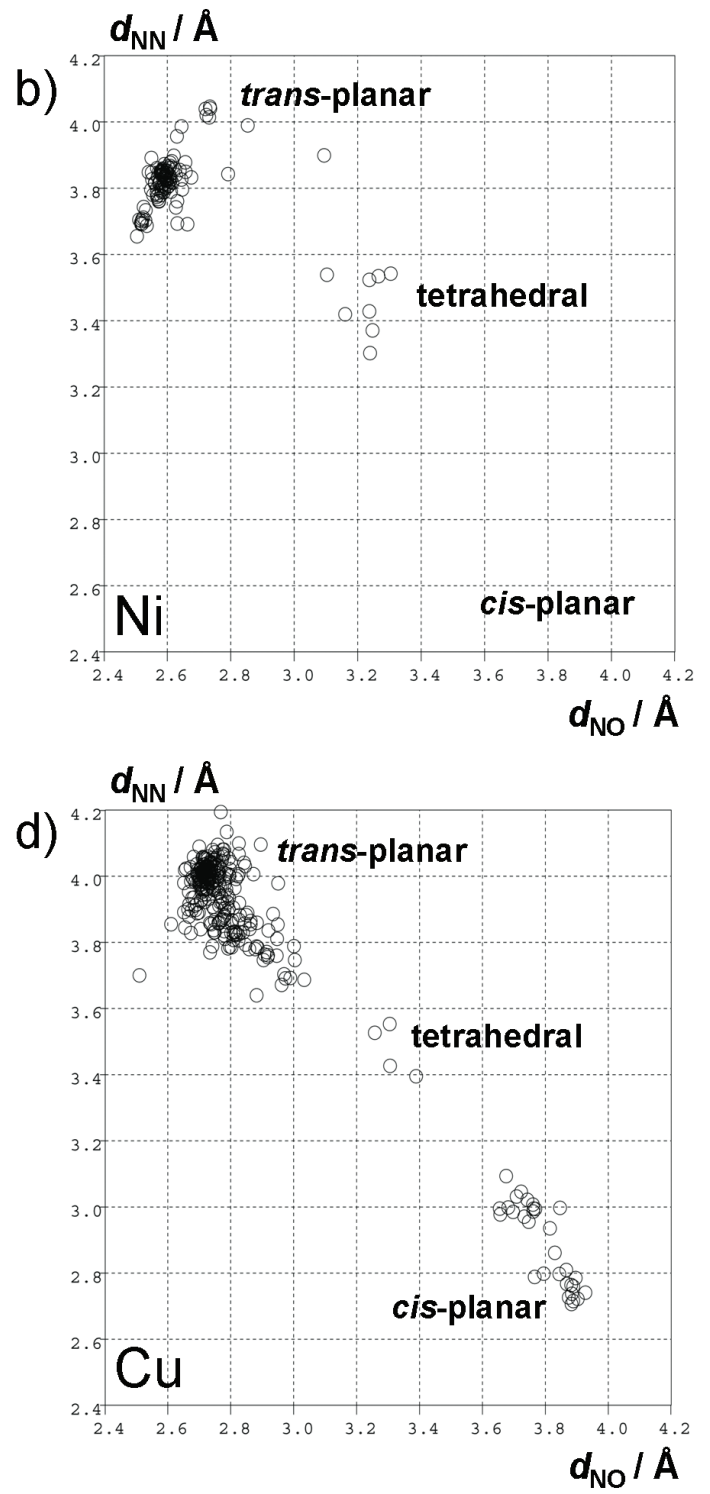

Fig. 21. The distribution of coordination geometries in mononuclear bis(bidentate Schiff base) coordination compounds in the CSD. a) A diagram of the molecular fragment used for the CSD search with the definition of parameters $d_{\mathrm{NN}}$ and $d_{\mathrm{NO}}$ b) $d_{\mathrm{NN}} / d_{\mathrm{NO}}$ correlation for nickel(II) complexes (116 data points), c) $d_{\mathrm{NN}} / d_{\mathrm{NO}}$ correlation for cobalt(II) complexes (38 data points), d) $d_{\mathrm{NN}} / d_{\mathrm{NO}}$ correlation for copper(II) complexes (277 data points). For detailed discussion see text. 
rahedraly deformed, but can show an increase of both $d_{\mathrm{NN}}$ and $d_{\mathrm{NO}}$ compared to a 'perfect' square due to stepwise bending of complex molecules, as will be discussed below. Cis-planar Ni(II) complexes occur only in polynuclear species where the Schiff base ligands bridge between two or more metal ions as well as in complexes with tetradentate Schiff bases usually derived from diamines such as $o$-phenylenediamine [23].

Although it is commonly accepted that the stereochemistry of cobalt(II) is similar to that of nickel(II), there is a marked increase of the occurrence of tetrahedral bis(bidentate Schiff base)cobalt(II) complexes in comparison to those of nickel(II) with tetrahedral coordination seemingly to be preferred to trans-planar coordination. Cis-planar coordination is entirely absent as is among the nickel compounds.

The coordination to copper(II) is usually less rigid than that to cobalt and nickel. This is demonstrated in the $d_{\mathrm{NN}} / d_{\mathrm{NO}}$ plot by the smearing of the data points along the line connecting top left and bottom right corners of the plot. This corresponds to the rotation of one chelate ring plane in respect to the other and indicates that such rotation is energetically less demanding than in corresponding copper and nickel compounds. In spite of the smearing, the data points are still grouped into three well distin- guishable regions corresponding to trans-planar, tetrahedral and cis-planar. The majority of compounds exhibit a trans-planar coordination which can be somewhat distorted towards tetrahedral. The second most abundant group corresponds to the cis-planar coordinated species, while only four structures can be described as tetrahedraly coordinated (Figure 22). Another feature of copper(II) complexes is their tendency to form dimers $[127,128]$ and tetramers [129]. Formation of dimers can also be noticed in nickel(II) and cobalt(II) complexes but there it occurs much less frequently.

It is interesting to note that all the coordination polyhedra achievable in bis(bidentate Schiff base) complexes, other than the perfectly planar ones, are chiral. Although this usually does not affect the properties of the bulk material since the majority of reported structures crystallised as racemates, there are cases where the chirality of the coordination polyhedron dictates the chirality of crystal packing. An example of such behaviour is $\operatorname{bis}(\mu-N, N$ '-hexamethylenedisalicylaldiminato) dicopper(II), where chiral tetrahedraly disordered planar coordination of the copper ions leads to a helicity of binuclear coordination species and in turn to crystallization of enantiomeric compounds in enantiomeric space groups $P 4_{1}$ a)

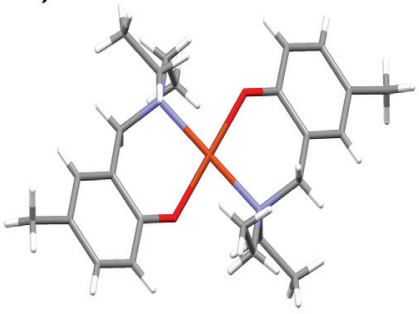

b)

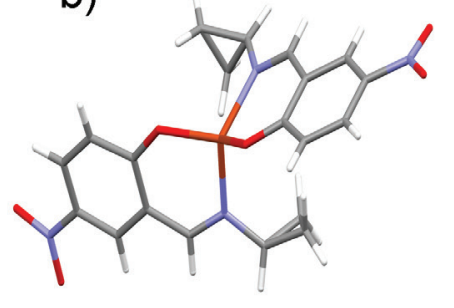

c)

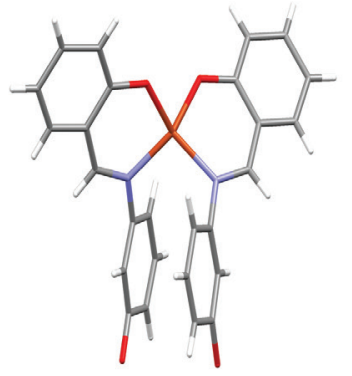

Fig. 22. Examples of limiting coordination geometries of bis(bidentate Schiff base)copper(II) complexes: a) trans-planar [131], b) tetrahedral [132], c) cis-planar [133]

a)

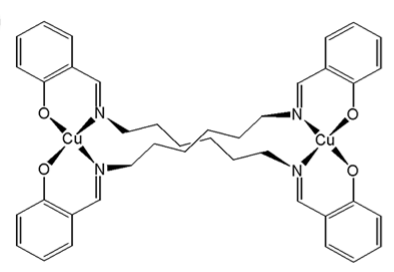

b)

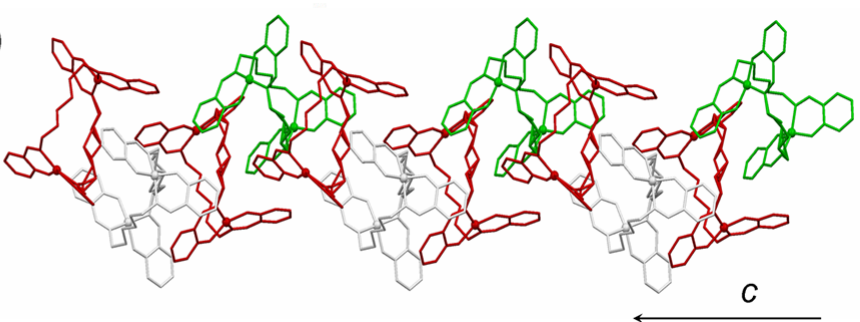

Fig. 23. a) Molecular diagram of $\operatorname{bis}\left(\mu-N, N^{\prime} \text {-hexamethylenedisalicylaldiminato)dicopper(II) }\right)^{30}$, b) Helical stacking of molecules along the $c$ axis exhibiting a $4_{1}$ symmetry 
and $P 4_{3}$ (Figure 23) [30]. By introducing chiral substituents on the Schiff base ligand itself, it is possible to control the chirality of the coordination sphere and thus the entire complex molecule. Many such complexes have been found to be potent chiral catalysts in organic synthesis [130].

A feature of the molecular geometry of many salicylaldimine and naphthaldimine bisbidentate complexes with divalent copper and nickel is their 'stepped' conformation arising from a distinct bend in the otherwise planar molecules along the line joining the two donors within each separate ligand. Such molecules are comprised of two planar regions which lie on parallel planes separated by a distance $S$ referred to as step distance (Figure 24). The step distance $S$ is defined as the perpendicular separation between the planes through the chelate ring and/or through the aromatic ring atoms [38, 121, 134].

The occurrence of 'stepped' conformation has been mainly associated with steric fac-

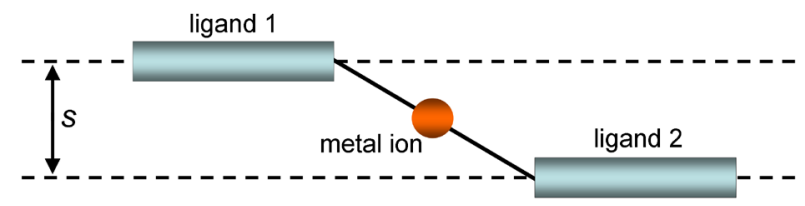

Fig. 24. A schematic representation of a complex molecule in a stepped conformation indicating the step distance $(\mathrm{S})$

a)

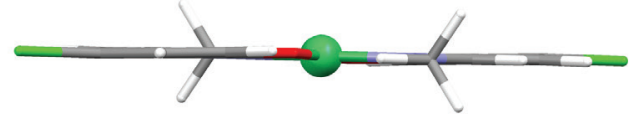

tors [134], and electronic effects [123]. However, steric and packing effects seem to have an important contribution to the formation of stepped conformation. Large $N$ substituents favour larger step distances. This is well demonstrated by comparing molecular conformations of $\operatorname{bis}(N$-methyl-5-chlorosalicylideneiminato) nickel(II) and bis( $N$-ethyl-5-chlorosalicylideneiminato)nickel(II). The methyl compound is almost planar (step distance $S=0.121 \AA$ ), while more bulky ethyl substituent renders the molecular conformation markedly stepped (step distance $S=0.702 \AA$ ) due to the close contact between the methylene hydrogen atoms of one ligand and the coordinated oxygen atom of the other (Figure 25) [38]. Complexes with bulkier $N$ substituents can exhibit even larger values of step distance, so that in bis( $N$-2-naphthyl-2-hydroxy-1-naphthaldiminato)nickel(II) the step distance is $S=0.639 \AA$ [113] and even larger in complexes of $N$-o-tolyl Schiff bases such as $\operatorname{bis}(N$-(2-methylphenyl)-2-hydroxy-1-naphthaldiminato)nickel(II) $(S=1.054 \AA)$ [31].

The conformation of the coordination polyhedron is also largely influenced by the crystal packing, sometimes even to a greater extent then the $N$-substituent. This is seen in the crystal structure of bis(3-ethoxysalicylideneiminato)nickel(II) (Figure 26) [22], for which a small step distance is expected since there is

b)

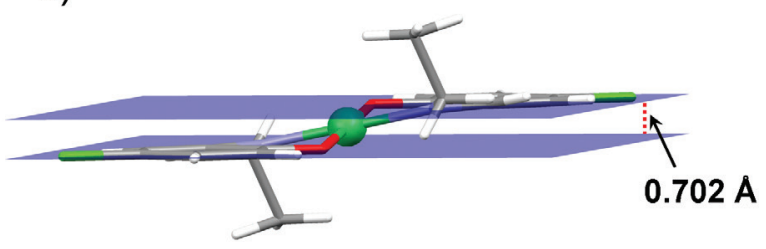

Fig. 25. Molecular structures of bis( $N$-methyl-5-chlorosalicylideneiminato)nickel(II) and bis( $N$-ethyl-5chlorosalicylideneiminato)nickel(II) ${ }^{38}$ viewed along the edge of the coordination plane.

The methyl derivative is almost perfectly planar, while the ethyl derivative adopts a stepped conformation.
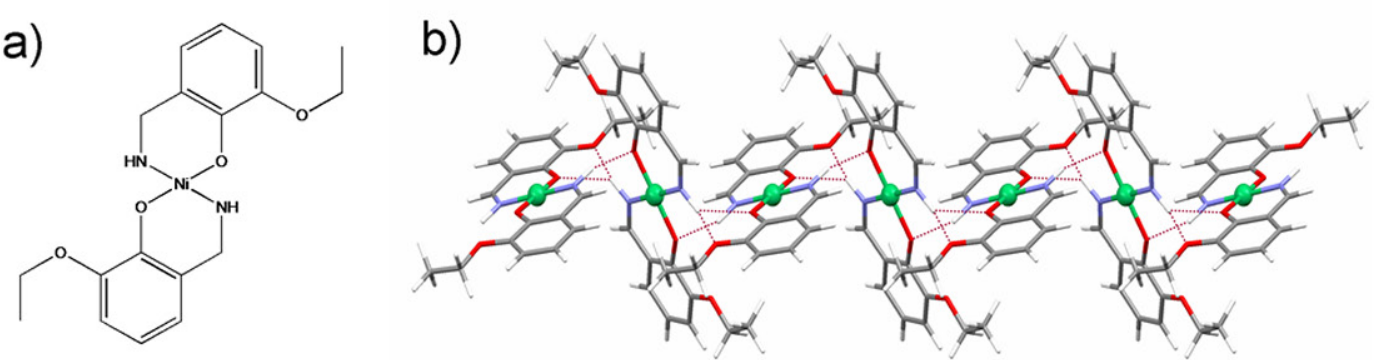

c)

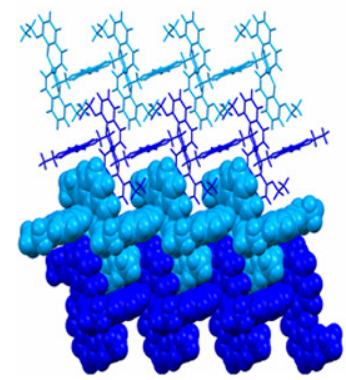

Fig. 26. Crystal packing of bis(3-ethoxysalicylideneiminato)nickel(II):

a) molecular diagram, b) hydrogen bonded chains, c) packing of chains [22] 
no $N$-substituent. In the crystal structure there are however two symmetrically non-equivalent molecules, which alternate in hydrogen bonded chains along the $b$ axis. Of these one is almost planar $(S=0.144 \AA$ ), while the other molecule has a step distance of $S=0.696 \AA$, which is more than in both $N$-methyl $(S=0.514 \AA)$, and $N$-ethyl $(S=0.616 \AA)$ derivative [22]. The difference between the two bis(3-ethoxysalicylideneiminato) nickel(II) molecules is in the nature of the interaction between the chelate rings of these molecules and the phenyl rings of molecules from a neighbouring chain - the chelate rings of the planar molecule participates in stacking interaction while the chelate rings of the stepped molecules are acceptors of $\mathrm{C}-\mathrm{H} \cdots \pi$ hydrogen bonds.

The effect of crystal packing can also be seen comparing the molecular conformations of bis( $N$-methylsalicylideneiminato)nickel(II) in its monoclinic and orthorhombic polymorphs where step distance in the monoclinic polymorph is quite large $(S=0.891 \AA)$, while in the orthorhombic one the molecule lies on a crystallographic mirror plane and is thus perfectly planar $(S=0 \AA)[37$, $135,136]$.

Acknowledgement: We are indebted to the Ministry of Science, Education and Sport of the Republic of Croatia for the long-lasting financial support in this field of investigation since early 1990's.

\section{REFERENCES}

[1] M. B. Smith, J. March, March's Advanced Organic Chemistry: Reactions, Mechanisms and Structure, $6^{\text {th }}$ ed., John Wiley \& Sons, Inc., Hoboken, New Jersey, 2007.

[2] F. A. Carey, Organic Chemistry, $5^{\text {th }}$ ed., The McGraw-Hill Companies, Inc., New York, 2003.

[3] L. F. Fieser, M. Fieser, Advanced Organic Chemistry, Reinhold Publishing Corporation, New York, 1961.

[4] H. Schiff, Mitteilungen aus dem Universitätslaboratorium in Pisa: Eine neue Reihe organischer Basen, Justus Liebigs Ann. Chem., 131, 118-119 (1864).

[5] U. Schiff, Sopra dei nuova seria di basi organiche, Giornale di Scienze Naturali ed Economiche, Vol. II, Palermo, 1-59 (1867).

[6] T. T. Tidwell, Hugo (Ugo) Schiff, Schiff Bases, and a Century of $\beta$-Lactam Synthesis, Angew. Chem. Int. Ed., 47, 1016-1020 (2008).

[7] K. Užarević, I. Đilović, D. Matković-Čalogović, D. Šišak, M. Cindrić, Anion-directed self-assembly of flexible ligands into anion-specific and highly symmetrical organic solids, Angew. Chem. Int. Ed., 47, 7022-7025 (2008).

[8] P. A. Vigato, S. Tamburini, The challenge of cyclic and acyclic Schiff bases and related derivatives, $\mathrm{Co}$ ord. Chem. Rev., 248, 1717-2128 (2004).

[9] P. D. Beer, P. A. Gale, Anion recognition and sensing: The state of the art and future perspectives, $A n$ gew. Chem. Int. Ed., 40, 486-516 (2001).

[10] F. H. Allen, The Cambridge Structural Database: a quarter of a million crystal structures and rising, Acta Crystallogr., B58, 380-388 (2002).

[11] R. H. Holm, G. W. Everett, A. Chakravorty, Metal complexes of Schiff bases and b-ketoamines, Progr. Inorg. Chem., 7, 83-214 (1966).

[12] M. Calligaris, L. Randaccio, Schiff Bases as Acyclic Polydentate Ligands in Comprehensive Coordination Chemistry; ed. G. Wilikinson, R. D. Gillard, J. A. McCleverty, Pergamon Press, New York, 2, 715-738 (1987).

[13] X. Zhou, X. Liu, X. Yang, D. Shang, J. Xin, X. Feng, Highly enantioselective hydrophosphonylation of aldehydes catalyzed by tridentate Schiff base aluminum(III) complexes, Angew. Chem. Int. Ed., 47, 392-394 (2008).

[14] K. C. Gupta, A. K. Sutar, Catalytic activities of Schiff base transition metal complexes, Coord. Chem. Rev., 252, 1420-1450 (2008).

[15] R. Kitaura, G. Onoyama, H. Sakamoto, R. Matsuda, S.-I. Noro, S. Kitagawa, Immobilization of a metallo Schiff base into a microporous coordination Polymer, Angew. Chem., Int. Ed., 43, 2684 2687 (2004).

[16] P. G. Lacroix, Second-order optical nonlinearities in coordination chemistry: The case of bis(salicylaldiminato)metal Schiff base complexes, Eur. J. Inorg. Chem., 339-348 (2001).

[17] S. Di Bella, I. Fragala, I. Ledoux, M. A. Diaz-Garcia, T. J. Marks, Synthesis, characterization, optical spectroscopic, electronic structure, and second-order nonlinear optical (NLO) properties of a novel class of donor-acceptor bis(salicylaldiminato)nickel(II) Schiff base NLO chromophores, J. Am. Chem. Soc., 119, 9550-9557 (1997).

[18] A. K. Sah, T. Tanase, M. Mikuriya, Tri- and Tetranuclear Copper(II) Complexes consisting of mononuclear $\mathrm{Cu}(\mathrm{II})$ chiral building blocks with a 
sugar-derived Schiff's base ligand, Inorg. Chem., 45, 2083-2092 (2006).

[19] J. Lewiński, J. Zachara, I. Justyniak, M. Dranka, Hydrogen-bond supramolecular structure of group 13 Schiff base complexes, Coord. Chem. Rev., 249, 1185-1199 (2005).

[20] M. Shiotsuka, Y. Okaue, N. Matsumoto, H. Okawa, T. Isobe, Crystal structures and single-crystal electron spin resonance spectra of $\pi \cdots \pi$ type molecular complexes of bis(1-methyliminomethyl-2-naphtholato)copper(II), J. Chem. Soc., Dalton Trans., 2065-2070 (1994).

[21] G. Rajsekhar, C. P. Rao, P. Saarenketo, K. Nattinen, $\mathrm{K}$. Rissanen, Complexation behaviour of hexadentate ligands possessing $\mathrm{N}_{2} \mathrm{O}_{4}$ and $\mathrm{N}_{2} \mathrm{O}_{2} \mathrm{~S}_{2}$ cores: differential reactivity towards $\mathrm{Co}(\mathrm{II}), \mathrm{Ni}(\mathrm{II})$ and $\mathrm{Zn}(\mathrm{II})$ salts and structures of the products, New J. Chem., 28, 75-84 (2004).

[22] B. Kamenar, B. Kaitner, A. Stefanović, Structures of three bis(3-ethoxy- $N$-R-salicylideneaminato) nickel(II) complexes ( $\mathrm{R}=\mathrm{H}$, methyl, ethyl), Acta Crystallogr., C46, 1627-1631 (1990).

[23] A. Blagus, B. Kaitner, Interactions between dimers of $\left\{1,1^{\prime}\right.$-[o-phenylenebis(nitrilomethylidyne) $] \mathrm{di}$-2naphtholato- $\left.{ }^{4} O, N, N^{\prime}, O^{\prime}\right\}$ nickel(II), Acta Crystallogr., C65, m455-m458 (2009).

[24] M. Dey, C. P. Rao, P. K. Saarenketo, K. Rissanen, E. Kolehmainen, P. Guionneau, $\mathrm{Mn}$ (IV) and $\mathrm{Co}(\mathrm{III})-$ complexes of - OH-rich ligands possessing $\mathrm{O}_{2} \mathrm{~N}, \mathrm{O}_{3} \mathrm{~N}$ and $\mathrm{O}_{4} \mathrm{~N}$ cores: syntheses, characterization and crystal structures, Polyhedron , 22, 3515-3521 (2003).

[25] A. Scheurer, H. Maid, F. Hampel, R. W. Saalfrank, L. Toupet, P. Mosset, R. Puchta, N. J. R. van E. Hommes, Conformation of salen complexes on the ctereochemistry of the asymmetric epoxidation of olefins, Eur. J. Org. Chem., 2566-2574 (2005).

[26] M. Farahbakhsh, H. Nekola, H. Schmidt, D. Rehder, Thio-Ligation to Vanadium: The NSSN and $\mathrm{S}^{\prime} \mathrm{N}^{\prime} \mathrm{O}$ Donor Sets $\left(\mathrm{N}=\right.$ Pyridine, $\mathrm{N}^{\prime}=$ Enamine; $\mathrm{S}$ $=$ Thioether, $\mathrm{S}^{\prime}=$ Thiolate), Chem. Ber., 130, 11291133 (1997).

[27] Zhong Yu, T. Kuroda-Sowa, H. Kume, T. Okubo, M. Maekawa, M. Munakata, Effects of metal doping on the spin-crossover properties of an iron(II) complex with extended $\pi$-conjugated Schiff-base ligand having an $\mathrm{N}_{4} \mathrm{O}_{2}$ donor set, Bull. Chem. Soc. Jpn., 82, 333-337 (2009).

[28] Y. Elerman, I. Svoboda, [N-(2-Mercaptophenyl)2-hydroxynaphthaldiminato](pyridine)nickel(II), Acta Crystallogr., C52, 2705-2707 (1996).

[29] J. J. Zhang, H.-J. Zhou, A. Lachgar, Directed Assembly of cluster-based supramolecules into onedimensional coordination polymers, Angew. Chem.,
Int. Ed., 46, 4995-4998 (2007).

[30] T. Friščić, A. J. Lough, G. Ferguson, B. Kaitner, Enantiomeric $\operatorname{bis}\left(\mu-N, N^{\prime}-\right.$ hexamethylenedisalicylaldiminato)dicopper(II) complexes, Acta Crystallogr., C58, m313-m315 (2002).

[31] B. Kaitner, E. Meštrović, G. Pavlović, N-o-tolyl2-hydroxy-1-naphthaldimine and its $\mathrm{Ni}^{\mathrm{II}}$ complex. Conformational changes of free ligand by chelatation, J. Chem. Cryst., 28, 77-82 (1998).

[32] W. X. Zhang, C.-Q. Ma, S.-F. Si, Synthesis, structure and electrochemistry of a copper(II) complex with 1,2-di $\{o$-[o-hydroxy(naphthylideneimino) $]$ phenoxy $\}$ ethane, Transition Met. Chem., 26, 380-383 (2001).

[33] S. M. El-Medani, O. A. M. Ali, R. M. Ramadan, Photochemical reactions of group 6 metal carbonyls with $N$-salicylidene-2-hydroxyaniline and bis(salicylaldehyde)phenylenediimine, J. Mol. Struct., 738, 171-177 (2005).

[34] M. L. Tong, X.-M. Chen, B.-H. Ye, L.-N. Ji, Self-assembled three-dimensional coordination polymers with unusual ligand-unsupported $\mathrm{Ag}-\mathrm{Ag}$ bonds: syntheses, structures, and luminescent properties, Angew. Chem., Int. Ed., 38, 2237-2240 (1999).

[35] M. Hosseini, S. F. L. Mertens, M. Ghorbani, M. R. Arshadi, Asymmetrical Schiff bases as inhibitors of mild steel corrosion in sulphuric acid media, Mater. Chem. Phys., 78, 800-808 (2003).

[36] M. Dey, C. P. Rao, P. K. Saarenketo, K. Rissanen, Mono-, di- and tri-nuclear Ni(II) complexes of $N$-, $O$-donor ligands: structural diversity and reactivity, Inorg. Chem. Commun., 5, 924-928 (2002).

[37] B. Kamenar, B. Kaitner, G. Ferguson, T. N. Waters, A Redetermination of the structures of bis(salicylideneaminato)nickel(II) and monoclinic and orthorhombic forms of bis( $N$-methylsalicylideneaminato)nickel(II), Acta Crystallogr., C46, 1920-1923 (1990).

[38] T. C. Jones, T. N. Waters, B. Kaitner, B. Kamenar, The crystal structure and conformation of bis $(\mathrm{N}$ methyl-5-chlorosalicylideneaminato)nickel(II) and Bis( $N$-ethyl-5-chlorosalicylideneaminato)nickel (II), Croat. Chem. Acta, 59, 825-831 (1986).

[39] G. Pavlović, Stereochemistry of Polydentate Schiff Bases and Their Complexes with Vanadium, Cobalt, Nickel and Copper, Ph. D. Thesis, Faculty of Science, University of Zagreb, Zagreb, 1997.

[40] B. Kamenar, B. Kaitner, A. Stefanović, T. N. Waters, Structures of bis( $N$-methyl-5-nitrosalicylideneaminato)nickel(II), Acta Crystallogr., C46, 1923-1925 (1990).

[41] S. Gabud, B. Sc. Thesis, Faculty of Science, University of Zagreb, Zagreb, 1997.

[42] S. Jambrešić, B. Sc. Thesis, Faculty of Science, 
University of Zagreb, Zagreb, 1995.

[43] B. Kaitner, G. Pavlović, Hydrogen Bonded Dimer $N$-(2-hydroxyethyl)-2-oxy-1-naphthaldimine and Its Oxo-vanadium(V) Complex, Croat. Chem. Acta, 72, 607-620 (1999).

[44] T. Friščić, B. Sc. Thesis, Faculty of Science, University of Zagreb, Zagreb, 2001.

[45] B. Kaitner, G. Pavlović, A Reinvestigation of the quinoidal effect in $N$-n-propyl-2-oxo-1-naphthylidene-methylmine, Acta Crystallogr., C52, 25732575 (1996).

[46] A. Blagus, Preparation and characterization of polydentate Schiff bases derived from $O$-hydroxyaryl aldehydes and ketones with aromatic diamines, M. Sc. Thesis, Faculty of Science, University of Zagreb, Zagreb, 2005.

[47] A. Blagus, Influence of intermolecular interactions on stereochemistry of polydentate Schiff bases and theirs complexes with nickel and copper, $\mathrm{Ph}$. D. Thesis, Faculty of Science, University of Zagreb, Zagreb, 2008.

[48] D. Cinčić, Schiff bases derived from 2-hydroxy1-naphthaldehyde with aromatic monoamines and their copper(II), nickel(II) and cobalt(II) complexes, Ph. D. Thesis, Faculty of Science, University of Zagreb, Zagreb, 2009.

[49] H. K. Shapiro, Carbonyl-trapping therapeutic strategies, Am. J. Ther., 5 , 323-353 (1998).

[50] Chen, H., Rhodes, J., Schiff base forming drugs: Mechanisms of immune potentiation and therapeutic potential, J. Mol. Med., 74, 497-504 (1996).

[51] V. Ambike, S. Adsule, F. Ahmed, Z. Wang, Z. Afrasiabi, E. Sinn, F. Sarkar, S. Padhye, Copper conjugates of nimesulide Schiff bases targeting VEGF, $\mathrm{COX}$ and Bcl-2 in pancreatic cancer cells, J. Inorg. Biochem., 101, 1517-1524 (2007).

[52] M. Singh, Transferrin as a targeting ligand for liposomes and anticancer drugs, Curr. Pharm. Des., 5, 443-451(1999).

[53] O. P. Anderson, A. la Cour, M. Findeisen, L. Hennig, O. Simonsen, L. F. Taylor, H. Toftlund, Zinc(II) $\mathrm{N}_{2} \mathrm{~S}_{2}$ Schiff-base complexes incorporating pyrazole: syntheses, characterization, tautomeric equilibria and racemization kinetics, J. Chem. Soc., Dalton Trans., 111-120 (1997).

[54] S. Uhlenbrock, R. Wegner, B. Krebs, Syntheses and characterization of novel tri- and hexa-nuclear zinc complexes with biomimetic chelate ligands, $J$. Chem. Soc., Dalton Trans., 3731-3736 (1996).

[55] H. Dürr, Perspectives in Photochromism: A Novel System based on the 1,5-electrocyclization of heteroanalogous pentadienyl anions, Angew. Chem., Int. Ed., 28, 413-431 (1989).
[56] H. Dürr, H. Bouas-Laurent, Photochromism: Molecules and Systems, Elsevier, Amsterdam, 1990.

[57] E. Hadjoudis, I. M. Mavridis, Photochromism and thermochromism of Schiff bases in the solid state: Structural aspects, Chem. Soc. Rev., 33, 579-588 (2004).

[58] G. H. Brown, Photochromism: Techniques of Chemistry, Vol. III, Wiley-Interscience, New York, 1971.

[59] M. Gavranić, B. Kaitner, E. Meštrović, Intramolecular $\mathrm{N}-\mathrm{H} \cdots \mathrm{O}$ hydrogen bonding, quinoid effect and partial $\pi$-electron delocalization in $N$-aryl Schiff bases of 2-hydroxy-1-naphthaldehyde: the crystal structures of planar $N$-( $\alpha$-naphthyl)- and $N$-( $\beta$-naphthyl)-2-oxy-1-naphthaldimine, J. Chem. Cryst., 26, 23-28 (1996).

[60] H. Pizzala, M. Carles, W. E. E. Stone, A. Thevand, Tautomerism in Schiff bases derived from 3-hydroxysalicyl-aldehyde. Combined X-ray diffraction, solution and solid state NMR study, J. Chem. Soc. Perkin Trans., 2, 935-939 (2000).

[61] Y. Kurono, H. Tamaki, Y. Yokota, M. Ida, C. Sugimoto, T. Kuwayama, K. Ikeda, T. Yashiro, Kinetics and mechanism of tautomerism of a hydroxy Schiff base, $N$-[2-\{-hydroxyethylimino(methyl)methyl phenyl]-2-chlorpropamide, in solution, Chem. Pharm. Bull., 42, 344-348 (1994).

[62] A. Filarowski, T. Głowiaka, A. Kolla, Strengthening of the intramolecular $\mathrm{O} \cdots \mathrm{H} \cdots \mathrm{N}$ hydrogen bonds in Schiff bases as a result of steric repulsion, $\mathrm{J}$. Mol. Struct., 484, 75-89 (1999).

[63] H. Nazır, M. Yıldız, H. Yilmaz, M. N. Tahir, D. Ülkü, Intramolecular hydrogen bonding and tautomerism in Schiff bases. Structure of $\mathrm{N}$-(2pyridil)-2-oxo-1-naphthylidenemethylamine, $J$. Mol. Struct., 524, 241-250 (2000).

[64] W. Schilf, B. Kamieński, T. Dziembowska, Intramolecular hydrogen bond investigation in Schiff bases derivatives of 2-hydroxy-1-naphthaldehyde and 2-hydroxy-1-acetonaphthone in $\mathrm{CDCl}_{3}$ solution and in the solid state by NMR methods $J$. Mol. Struct., 602-603, 41-47 (2002).

[65] K. Wozniak, H. He, J. Klinowski, W. Jones, T. Dziembowska E. Grech, Intramolecular hydrogen bonding in $N$-salicylideneanilines. X-ray diffraction and solid-state NMR studies, J. Chem. Soc., Faraday Trans., 91, 77-85 (1995).

[66] K. Užarević, M. Rubčić, V. Stilinović, B. Kaitner, M. Cindrić, Keto-enol tautomerism in asymmetric Schiff bases derived from $p$-phenylenediamine, $J$. Mol. Struc., 984, 232-239 (2010).

[67] A. Elmali, M. Kabak, E. Kavlakoglu, Y. Elerman, T. N. Durlu, Tautomeric properties, conformations and structure of $N$-(2-hydroxy-5-chlorophenyl) sal- 
icylaldimine, J. Mol. Struct., 510, 207-214 (1999).

[68] H. Ünver, Crystal structure and spectroscopic studies of bis[ $N$-(2-iodo)-naphthaldiminato $]$ copper(II), J. Mol. Struct., 641, 35-40 (2002).

[69] J. M. Fernández-G, F. del Rio-Portilla, B. QuirozGarcía, R. A. Toscano, R. Salcedo, The structures of some ortho-hydroxy Schiff base ligands, J. Mol. Struct., 561, 197-207 (2001).

[70] H. Ünver, A. Karakaş, A. Elmali, T. N. Durlu, The investigation of nonlinear optical properties of $N$-(3-fluorophenyl)naphthaldimine, J. Mol. Struct., 737, 131-137 (2005).

[71] A. Filarowski, A. Koll, T. Głowiak, Structure and hydrogen bonding in ortho-hydroxy Ketimines, $J$. Mol. Struct., 644, 187-195 (2003).

[72] A. Filarowski, A. Koll, T. Głowiak, Proton transfer equilibrium in the intramolecular hydrogen bridge in sterically hindered Schiff bases, J. Mol. Struct., 615, 97-108 (2002).

[73] A. Blagus, B. Kaitner, Solvent-induced Polymorphism of 2-[(2-Amino-phenylimino)-phenyl-methyl]-phenol, J. Chem. Cryst., 37, 473477(2007).

[74] E. M. Opozda, W. Łasocha, B. Włodarczyk-Gajda, Synthesis and characterisation of unsymmetrical Schiff bases derived from 3,4-diaminopyridine. Crystal and molecular structure of hydrogen-bonded dimers of 3-\{[(4-aminopyridin-3-yl)amino] methylene\} pentane-2,4-dione, J. Mol. Struct., 784, 149-156 (2006).

[75] A. Karakaş, A. Elmali, H. Ünver, I. Svoboda, Nonlinear optical properties of some derivatives of salicylaldimine-based ligands J. Mol. Struct., 702, 103-110 (2004).

[76] Z. Popović, V. Roje, G. Pavlović, D. MatkovićČalogović, G. Giester, The first example of coexistence of the ketoamino-enolimino forms of diamine Schiff base naphthaldimine parts: the crystal and molecular structure of $N, N^{\prime}$-bis(1-naphthaldimine)$o$-phenylenediamine chloroform $(1 / 1)$ solvate at 200 K, J. Mol. Struct., 597, 39-47 (2001).

[77] Y. Özcan, S. İde, İ. Şakıyan, E. Logoglu, Structure and characterization of $N$-(2-hydroxy-1-naphthylidene) threonine, J. Mol. Struct., 658, 207-213 (2003).

[78] H. Ünver, T. N. Durlu, Crystal structure and conformational analysis of 1-[N-(2-bromophenyl)]naphthaldimine, J. Mol. Struct., 655, 369-374 (2003).

[79] C. B. Aakeröy, A. M. Beatty, D. S. Leinen, Syntheses and crystal structures of new "extended" building blocks for crystal engineering: (Pyridylmethylene)aminoacetophenone oxime ligands, Crystal Growth and Design 1, 47-52 (2001).

[80] M. Ghazzali, V. Langer, C. Lopes, A. Eriksson,
L. Öhrström, Syntheses, crystal structures, optical limiting properties, and DFT calculations of three thiophene-2-aldazine Schiff base derivatives, New. J. Chem., 31, 1777-1784 (2007).

[81] S. Katsiaouni, S. Dechert, R. P. Briñas, C. Brückner, F. Meyer, Schiff base macrocycles containing pyrroles and pyrazoles, Chem. Eur. J., 14, 48234835 (2008).

[82] A. L. Pickering, G. Seeber, D.-L Long, L. Cronin, The importance of $\pi-\pi, \pi-\mathrm{CH}$ and $\mathrm{N}-\mathrm{CH}$ interactions in the crystal packing of Schiff-base derivatives of cis,cis- and cis,trans-1,3,5- triaminocyclohexane, CrystEngComm 7, 504-510 (2005).

[83] J. P. Jasinski, R. J. Butcher, A. N. Mayekar, H. S. Yathirajan, B. Narayana, B. K. Sarojini, Synthesis, crystal structures and theoretical studies of four Schiff bases derived from 4-hydrazinyl8-(trifluoromethyl) quinoline, J. Mol. Struct., 980, 172-181 (2010).

[84] T. Kudernac, N. Sändig, T. F. Landaluce, B. J. Van Wees, P. Rudolf, N. Katsonis, F. Zerbetto, B. L. Feringa, Intermolecular repulsion through interfacial attraction: Toward engineering of polymorphs, $J$. Am. Chem. Soc. 131, 15655-15659 (2009).

[85] O. Q. Munro, S. D. Strydom, C. D. Grimmer, Complementary hydrogen bonding in a new tridentate Schiff base ligand: X-ray, DFT and solution NMR studies, New J. Chem., 28 34-42 (2004).

[86] I. J. Bruno, J. C. Cole, P. R. Edgington, M. Kessler, C. F. Macrae, P. McCabe, J. Pearson, R. Taylor, New Software for searching the Cambridge Structural Database and visualizing crystal structures, Acta Crystallogr., B58, 389-397 (2002).

[87] CCDC Vista - A program for the analysis and display of data retrieved from the CSD, Cambridge crystallographic data centre, 12 Union Road, Cambridge, England, (1994).

[88] J. Lin, G.-H. Cui, J.-R. Li, S.-S. Xu, 3-\{[(2,6-Diisopropylphenyl)imino]methyl\}-2-naphthol, Acta Crystallogr., E61, o627-0628 (2005).

[89] K. Takano, M. Takahashi, T. Fukushima, T. Shibahara, 1-[(2-Methyl-8-quinolyl)aminomethylene]naphthalen-2(1H)-one, Acta Crystallogr., E65, o3127 (2009).

[90] A. Elmali, Y. Elerman, I. Svoboda, H. Fuess, $N$ (3,5-Dichlorophenyl)naphthaldimine, Acta Crystallogr., C54, 974-976 (1998).

[91] X.-Y. Liu, Y.-H. Fan, Q. Wang, C.-F. Bi, Y.-F. Wang, 1-[(Z)-(5-Methyl-2-pyridyl)iminiomethyl]2-naphtholate, Acta Crystallogr., E66, o309 (2010).

[92] R. Exelby, R. Grinter, Phototropy (or Photochromism), Chem. Rev., 65, 247-260 (1965).

[93] A. J. Cruz-Cabeza, C. R. Groom, Identification, 
classification and relative stability of tautomers in the cambridge structural database, CrystEngComm, (2010), DOI: 10.1039/c0ce00123f.

[94] M. Akkurt, S. Ö. Yildirim, A. M. Asiri, V. McKee, 4-[(2-Hydroxy-1-naphthyl)methylideneamino] benzoic acid, Acta Crystallogr., E64, o682 (2008).

[95] T. Hökelek, N. Gündüz, Z. Hayvali, Z. Kilic, Schiff bases and their complexes with metal ions. I. 2-Hydroxy- $N$ - $n$-propyl-1-naphthaldimine (1) and bis(2hydroxy-[kappa] $O-N$-n-propyl-1-naphthaldiminato-[kappa]N)nickel(II) (2), Acta Crystallogr., C51, 880-884 (1995).

[96] S. Gao, L.-H. Huo, H. Zhao, S. W. Ng, 1-[(2-Carboxy-1-phenylethyl)iminiomethylene]naphth-2olate, Acta Crystallogr., E61, o192-o194 (2005).

[97] L. Tatar, H. Nazır, M. Gümüşer, C. Kale, O. Atakol, Synthesis, crystal structure and electrochemical behaviour of water soluble Schiff bases, Z. Kristallogr., 220, 639-642 (2005).

[98] E. Hadjoudis, M. Vittorakis, I. Moustakali-Mavridis, Photochromism and thermochromism of Schiff bases in the solid state and in rigid glasses. Tetrahedron, 43, 1345-1360 (1987).

[99] E. Hadjoudis, Photochromism and thermochromism of $N$-salicylideneanilines and $N$-salicylideneamino-pyridines, J. Photochem., 17, 355-363 (1981)

[100] T. Friščić, B. Kaitner, E. Meštrović, Synthesis and structure of $N, N^{\prime}$-butylene- and $N, N^{\prime}$ hexylenebis(2-oxy-1-naphthaldimine), Croat. Chem. Acta, 71, 87-98 (1998).

[101] G. R. Desiraju, Supramoleculart synthons in Ccrystal engineering - A New Organic Synthesis, Angew. Chem. Int. Ed. Engl., 34, 2311-2327 (1995).

[102] T. Steiner, The hydrogen bond in the solid state, Angew. Chem. Int. Ed., 41, 48-76 (2002).

[103] C. A. Hunter, J. K. M. Sanders, The nature of p-p interactions, J. Am. Chem. Soc., 112, 5525-5534 (1990).

[104] F. Arod, M. Gardon, P. Pattison, G. Chapuis The [alpha]2-polymorph of salicylideneaniline, Acta Crystallogr., C61, o317-o320 (2005).

[105] X.-X. Gong, H.-J. Xu, 4-(2-Hydroxybenzylideneamino)benzonitrile, Acta Crystallogr., E64, o1188 (2008).

[106] C. C. Ersanli, Ç. Albayrak, M. Odabasoglu, A. Erdönmez 4-(2-Hydroxyphenyliminomethylene)phenol, Acta Crystallogr., E60, o389-o391 (2004

[107] S. M. Aldoshin, M. I. Knyazhanskii, Ya. R. Tymyanskii, L. O. Atovmyan, O. A. Dyachenko, Effect of intermolecular interactions on photo- and thermochromic properties of crystalline salicylalde- hyde arylimines, Khim. Fiz. (Sov. J. Chem. Phys.) 1015-1023 (1982).

[108] J. Burgess, J. Fawcett, D. R. Russell, S. R. Gilani V. Palma Four $N$-(2-hydroxybenzylidene)aniline derivatives Acta Crystallogr., C55, 1707-1710 (1999).

[109] S. Yüce, A. Özek, Ç. Albayrak, M. Odabasoglu, O. Büyükgüngör, A redetermination of 1-\{4-[(2-hydroxybenzylidene)amino]phenyl $\}$ ethanone, Acta Crystallogr., E60, o716-o717 (2004).

[110] J. J. McKinnon, M. A. Spackman i A. S. Mitchell, Novel tools for visualizing and exploring intermolecular interactions in molecular crystals, Acta Crystallogr. B60, 627-668 (2004).

[111] B. Kaitner, G. Pavlović, $N$ - $p$-Tolylvanillaldimine, Acta Crystallogr., C51, 1875-1878 (1995).

[112] Z.-H. Ni, H.-L. Wang, 6-Methoxy-2-(2-pyridylmethyliminomethyl)phenol, Acta Crystallogr., E64, 03799 (2008).

[113] V. Stilinović, D. Cinčić, B. Kaitner, The effect of $\mathrm{CH} \cdots \mathrm{N}$ interactions on crystal structure and thermal properties of two novel diamine Schiff bases derived from terephthaldialdehyde, Acta Chim. Slov., 55, 874-879 (2008).

[114] J.-C. Zhou, C.-M. Zhang, N.-X. Li, Z.-Y. Zhang, (Z)-2-[(2-Hydroxy-1-naphthyl)methyleneamino] benzonitrile, Acta Crystallogr., E65, o1700 (2009).

[115] Y.-F. Zhao, J.-P. Xiong, Y. Zuo, (Z)-1-[(3-Cyanophenyl)iminiomethyl]-2-naphtholate, Acta Crystallogr., E65, o1477 (2009).

[116] A. Filarowski, A. Kochel, M. Kluba, F. S. Kamounah, Structural and aromatic aspects of tautomeric equilibrium in hydroxy aryl Schiff bases, J. Phys. Org. Chem., 21, 939-944 (2008).

[117] G. Pavlović, J. M. Sosa 3-[(2-Oxo-1-naphthylidene)methylamino]benzoic acid, Acta Crystallogr., C56, 1117-1119 (2000).

[118] Y.-J. Hu, H. Ho. Zou, M.-H. Zeng, N. S. Weng, Two bis-[1-(aryliminomethyleny)-2-oxy-naphthalen] nickel catalysts for the polymerization of methyl methacrylate, J. Organomet.Chem., 694, 366-372 (2009).

[119] M. Gavranić, B. Kaitner, E. Meštrović, Bis[N-( $\beta-$ naphthyl)-2-oxy-1-naphthaldiminato]-nickel(II), Acta Crystallogr., C53, 1232-1234 (1997).

[120] A. D. Garnovskii, A. P. Sadimenko, M. I. Sadimenko, D. A. Garnovskii, Common and less-common coordination models of the typical chelating and heteroaromatic ligands, Coord. Chem. Rev., 173, (1998) 31.

[121] R. H. Holm, M. J. O’Connor, Stereochemistry of Bis-Chelate Metal(II) Complexes, Progr. Inorg. 
Chem., 14, 241-401 (1971).

[122] A. D. Garnovskii, A. L. Nivorozhin, V. I. Minkin, Ligand environment and the structure of Schiff base adducts and tetracoordinated metal-chelates, Coord. Chem. Rev., 126, 1-69 (1993).

[123] H. S. Maslen, T. N. Waters, The conformation of Schiff-base complexes of copper(II): a stereoelectronic view, Coord. Chem. Rev., 17, 137-176 (1975).

[124] J. M. Fernández-G, M. J. Rosales-Hoz, M. F. Rubio-Arroyo, R. Salcedo, R. A. Toscano, A. Vela, Synthesis, crystal structure, and EHMO calculations for the nickel(II) complexes of imines derived from salicylaldehyde, 2-hydroxy-1-naphthaldehyde, and 3-hydroxy-2-naphthaldehyde, Inorg. Chem., 26, 349-357 (1987).

[125] Ivan Castillo, Juan M. Fernández-González, José Luis Gárate-Morales, Synthesis and solid state structures of copper(II) complexes of Schiff bases derived from cyclopropyl and cyclobutylamine, $J$. Mol. Struct., 657, 25-35 (2003).

[126] M. Aguilar-Martínez, R. Saloma-Aguilar, N. Macías-Ruvalcaba, R. Cetina-Rosado, A. Navarrete-Vázquez, V. Gómez-Vidales, A. Zentella-Dehesa, R. A. Toscano, S. Hernández-Ortega, J. M. Fernández-G, Synthesis, crystal structures, spectroscopic and electrochemical properties of homologous series of copper(II) complexes of Schiff bases derived from cycloalkylamines, $J$. Chem. Soc., Dalton Trans., 2346-2352 (2001).

[127] K. Liu, G. Liu, Z. Cao, M. Niu, Bis \{m-1-[(2-oxidophenyl)iminomethyl]-2 naphtholato $\}$ bis[pyridine copper(II)], Acta Crystallogr., E66, m78 (2010).

[128] G. R. Clark, J. M. Waters, T. N. Waters, G. J. Williams, Polymorphism in Schiff base complexes of copper(II): the crystal and molecular structure of a second brown form of bis( $\mathrm{N}$-methyl-2-hydroxy1-naphthaldiminato)copper(II), J. Inorg. Nucl. Chem., 39, 1971-1975 (1977).
[129] J.-F. Dong, L.-Z. Li, T. Xu, H. Cui, D.-Q. Wang, Tetrakis $\left\{\mu_{3}-1-[(2\right.$-oxidoethyl)iminomethyl]2-naphtholato tetracopper(II), Acta Crystallogr., E63, m1501-m1502 (2007).

[130] A. W. Kleij, Nonsymmetrical salen ligands and their complexes: synthesis and applications, Eur. J. Inorg. Chem., 193-205 (2009) and references there in.

[131] F. Connac, N. Habaddi, Y. Lucchese, M. Dartiguenave, L. Lamandé, M. Sanchez, .1 Simard, A. L. Beauchamp, Zinc(II) and copper(II) complexes of monoanionic chelating phenolato ligands containing an amine donor. Crystal and molecular structure of the $\left(\mathrm{Et}_{3} \mathrm{NH}\right)\left[\mathrm{ZnCl}_{2} \mathrm{~L}\right]$ and $\mathrm{CuL}_{2}$ compounds with $\mathrm{L}=2-[($ diethylamino)methyl $]-4-$ methylphenolate, Inorg. Chim. Acta, 265, 107-114 (1997).

[132] X.-Q. Han, G.-R. Yue, Crystal Structure of bis[Ncyclopropyl-5-nitrosalicylaldiminato]copper(II), $\mathrm{Cu}\left[\left(\mathrm{C}_{3} \mathrm{H}_{5} \mathrm{NCH}\right)(\mathrm{O}) \mathrm{C}_{6} \mathrm{H}_{3}\left(\mathrm{NO}_{2}\right)\right]_{2}, \quad$ Z. Kristallogr. NCE, 221, 73-74 (2006).

[133] Y. Shibuya, K. Nabari, M. Kondo, S. Yasue, K. Maeda, F. Uchida, H. Kawaguchi, The copper(II) complex with two didentate Schiff base ligands. The unique rearrangement that proceeds under alcohol vapor in the solid state to construct noninclusion structure, Chem. Lett., 37, 78-79 (2008).

[134] H. Tamura, K. Ogawa, A. Takeuchi, S. Yamada, The molecular and crystal structure of the green form of $\operatorname{Bis}(N$-cyclohexylsalicylideneaminato $)$ copper(II), Bull. Chem. Soc. Jpn. 52, 3522-3527 (1979).

[135] E. Frasson, C. Panattoni, L. Sacconi, Studies in Coordination Chemistry. V. Structure of the Diamagnetic Bis-( $N$-methylsalicylaldimine)-nickel(II) Complex, J. Phys. Chem., 63, 1908-1911 (1959).

[136] M. R. Fox, E. C. Lingafelter, The crystal structure of the orthorhombic form of bis-( $N$-methylsalicylaldiminato)nickel, Acta Crystallogr., 22, 943-944 (1967). 